\title{
Marine mammal hotspots in the Greenland and Barents Seas
}

\author{
Charmain D. Hamilton ${ }^{1,12, *}$, Christian Lydersen ${ }^{1}$, Jon Aars ${ }^{1}$, Martin Biuw ${ }^{2}$, Andrei N. Boltunov ${ }^{3}$, \\ Erik W. Born ${ }^{4}$, Rune Dietz ${ }^{5}$, Lars P. Folkow ${ }^{6}$, Dmitri M. Glazov $^{7}$, Tore Haug ${ }^{2}$,

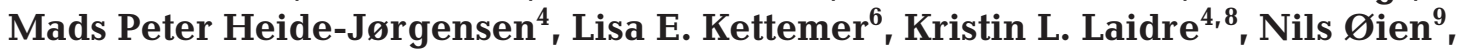 \\ Erling S. Nordøy ${ }^{6}$, Audun H. Rikardsen ${ }^{6,10}$, Aqqalu Rosing-Asvid ${ }^{4}$, Varvara Semenova ${ }^{3}$, \\ Olga V. Shpak ${ }^{7}$, Signe Sveegaard ${ }^{5}$, Fernando Ugarte ${ }^{4}$, Øystein Wiig ${ }^{11}$, Kit M. Kovacs ${ }^{1}$
}

\author{
${ }^{1}$ Norwegian Polar Institute, Fram Centre, 9296 Tromsø, Norway \\ ${ }^{2}$ Institute of Marine Research, Fram Centre, 9296 Tromsø, Norway \\ ${ }^{3}$ Marine Mammal Research and Expedition Center, Moscow 117218, Russia \\ ${ }^{4}$ Greenland Institute of Natural Resources, 3900 Nuuk, Greenland \\ ${ }^{5}$ Dept of Bioscience, Aarhus University, 4000 Roskilde, Denmark \\ ${ }^{6}$ Department of Arctic and Marine Biology, UiT - the Arctic University of Norway, 9019 Tromsø, Norway \\ ${ }^{7}$ A. N. Severtsov Institute of Ecology and Evolution, Russian Academy of Sciences, Moscow 119071, Russia \\ ${ }^{8}$ Applied Physics Lab, University of Washington, Seattle, WA 98105, USA \\ ${ }^{9}$ Institute of Marine Research, 5005 Bergen, Norway \\ ${ }^{10}$ The Norwegian Institute of Nature Research, Fram Centre, 9296 Tromsø, Norway \\ ${ }^{11}$ Natural History Museum, University of Oslo, 0562 Oslo, Norway \\ ${ }^{12}$ Present address: Fisheries and Oceans Canada, St. John's, NL A1C 5X1, Canada
}

ABSTRACT: Environmental change and increasing levels of human activity are threats to marine mammals in the Arctic. Identifying marine mammal hotspots and areas of high species richness are essential to help guide management and conservation efforts. Herein, space use based on biotelemetric tracking devices deployed on 13 species (ringed seal Pusa hispida, bearded seal Erignathus barbatus, harbour seal Phoca vitulina, walrus Odobenus rosmarus, harp seal Pagophilus groenlandicus, hooded seal Cystophora cristata, polar bear Ursus maritimus, bowhead whale Balaena mysticetus, narwhal Monodon monoceros, white whale Delphinapterus leucas, blue whale Balaenoptera musculus, fin whale Balaenoptera physalus and humpback whale Megaptera novaeangliae $;$ total $=585$ individuals) in the Greenland and northern Barents Seas between 2005 and 2018 is reported. Getis-Ord $G_{i}{ }^{*}$ hotspots were calculated for each species as well as all species combined, and areas of high species richness were identified for summer/autumn (Jun-Dec), winter/spring (JanMay) and the entire year. The marginal ice zone (MIZ) of the Greenland Sea and northern Barents Sea, the waters surrounding the Svalbard Archipelago and a few Northeast Greenland coastal sites were identified as key marine mammal hotspots and areas of high species richness in this region. Individual hotspots identified areas important for most of the tagged animals, such as common resting, nursing, moulting and foraging areas. Location hotspots identified areas heavily used by segments of the tagged

\footnotetext{
*Corresponding author: charmain.d.hamilton@gmail.com
}

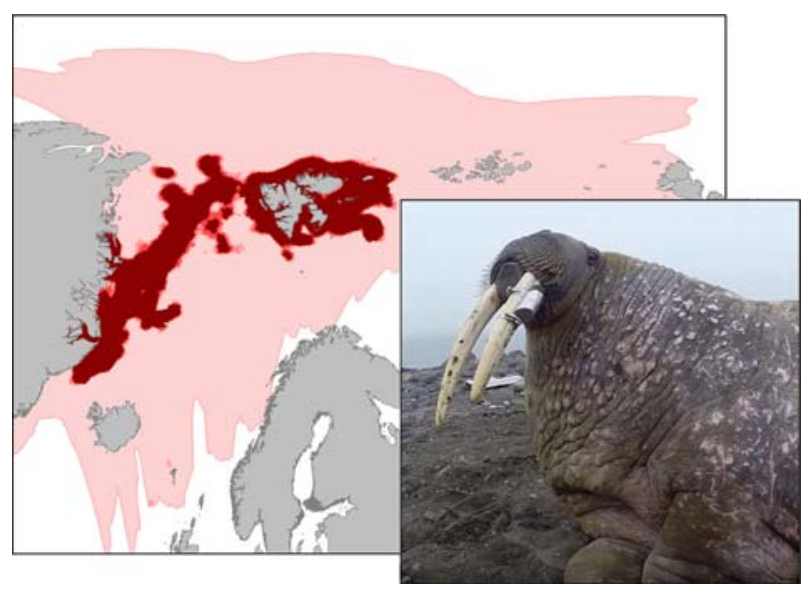

Getis-Ord $G_{i}^{*}$ plots highlight marine mammal hotspots in the Barents region-walruses were one of 13 species studied (using new custom-GPS tags) Photo: Kit M. Kovacs and Christian Lydersen; Image: C. D. Hamilton; NPI

populations, including denning areas for polar bears and foraging areas. The hotspots identified herein are also important habitats for seabirds and fishes, and thus conservation and management measures targeting these regions would benefit multiple groups of Arctic animals.

KEY WORDS: Ice-associated marine mammals $\cdot$ Seasonal migrants $\cdot$ Marginal ice zone $\cdot$ Svalbard $\cdot$ East Greenland $\cdot$ Climate change $\cdot$ Arctic $\cdot$ Biotelemetry

(C) The authors 2021. Open Access under Creative Commons by Attribution Licence. Use, distribution and reproduction are unrestricted. Authors and original publication must be credited. 


\section{INTRODUCTION}

The climate is changing faster in the Arctic than in any other area on Earth, with air temperatures increasing at a rate $2-3$ times the global average and sea-ice extent declining at an alarming rate (IPCC 2018, Meredith et al. 2019). Arctic endemic marine mammals are all strongly ice-affiliated and hence are seriously threatened by these changes (see Laidre et al. 2008, Kovacs et al. 2011, Meredith et al. 2019 for details). Numerous consequences of climate change have already been documented for this species group. Declines in Arctic sea ice and associated environmental changes have been linked to shifts in species distributions (e.g. Higdon \& Ferguson 2009, Hamilton et al. 2015, 2019a, Rode et al. 2015, Lone et al. 2018), changes in trophic relationships (e.g. Watt et al. 2016, Hamilton et al. 2017, Yurkowski et al. 2018) and increased risks of disease (e.g. Van Wormer et al. 2019). Concomitantly, levels of human activity, including shipping, tourism, commercial fishing, and oil and gas exploration and production, have increased and are likely to continue to do so in Arctic regions as sea-ice declines reduce logistical challenges for these industries (Reeves et al. 2014, Meredith et al. 2019). Thus, there is an acute need to identify important areas for marine mammals to allow for proper management and conservation of these species in the context of these multiple stressors (e.g. Kovacs et al. 2011, Reeves et al. 2014, Yurkowski et al. 2019).

Numerous marine mammal species inhabit the Greenland Sea and the northern Barents Sea. Three cetacean species (bowhead whale Balaena mysticetus, narwhal Monodon monoceros and white whale [beluga whale] Delphinaterus leucas) and the polar bear Ursus maritimus are Arctic endemic species that reside in these areas throughout the year (Kovacs et al. 2009, 2011). This region of the North Atlantic Arctic also contains 6 pinniped species. Three of these species (ringed seal Pusa hispida, bearded seal Erignathus barbatus and Atlantic walrus Odobenus rosmarus rosmarus) are endemic to the Arctic and live in close association with sea ice throughout the year. The harp seal Pagophilus groenlandicus and hooded seal Cystophora cristata are also dependent on sea ice. These species use the marginal ice zone (MIZ) in the Greenland Sea for pupping, nursing and moulting during the spring but are generally found in open water areas during the rest of the year (Kovacs et al. 2009, 2011). The harbour seal Phoca vitulina is generally considered to be a temperate seal species, but a population resides year round on the west coast of
Svalbard (Lydersen \& Kovacs 2010). A variety of cetacean species also use the Greenland and Barents Seas primarily during the summer and autumn as a foraging ground, including the killer whale Orcinus orca, the blue whale Balaenoptera musculus, the fin whale Balaenoptera physalus, the humpback whale Megaptera novaeangliae, the minke whale Balaenoptera acutorostrata, the sperm whale Physeter macrocephalus, the harbour porpoise Phocoena phocoena and the white-beaked dolphin Lagenorhynchus albirostris (Kovacs et al. 2009, Storrie et al. 2018).

Sea-ice extent is changing rapidly in the Greenland and Barents Seas, with the duration of sea-ice cover declining faster in the northern Barents Sea than in any other Arctic region $\left(41.8 \mathrm{~d} \mathrm{decade}^{-1}\right.$; Laidre et al. 2015a). Environmental conditions in Svalbard and the Barents Sea changed dramatically in the winter of 2005-2006, with the altered conditions persisting to the present day. The amount of land-fast ice forming in Svalbard's fjords declined sharply, especially along the west coast, and the location of the MIZ shifted northward (Hamilton et al. 2015, Pavlova et al. 2019). These changes were due in part to an increase in the temperature of Atlantic Water, in combination with more frequent penetration of Atlantic Water across the polar front, which, among other effects, has led to a 'borealization' of the fish and invertebrate communities in the Barents Sea (Fossheim et al. 2015, Tverberg et al. 2019). Levels of human activity in the Greenland and Barents Seas are increasing concomitant with the ongoing environmental changes. The Barents Sea (including the Svalbard Archipelago) is one of the most heavily trafficked regions in the High Arctic (Reeves et al. 2014). For example, the number of cruise vessels docking in Longyearbyen, the main settlement in Svalbard, tripled between 2007 and 2019 (Port of Longyearbyen 2020). Fishing activity is also expanding further north as sea ice recedes and currently occurs up to the northern ice edge, north of Svalbard (Reeves et al. 2014, ICES 2019). Hydrocarbon provinces are found throughout the Barents Sea and along the coast of East Greenland. Noise from air guns is already heard throughout the year in the western Fram Strait (Ahonen et al. 2017). Offshore oil and gas exploration and land-based mining are currently in the planning stage in East Greenland; some of these planned activities would involve extensive yearround shipping (Reeves et al. 2014).

The large-scale environmental changes and increasing levels of human activities in the Northeast Atlantic Arctic create a need to identify marine mam- 
mal hotspots to help guide management and conservation efforts. Observational data are limited from these areas due to a combination of factors, including few human communities, large expanses of sea ice, low levels of light up to 6 mo of the year and the cryptic, dispersed nature of many marine mammal species. In this study, data from 585 biotelemetry instruments deployed on 13 species of marine mammals (2005-2019) in the Greenland and northern Barents Seas (by 11 scientific institutes) were collated in order to investigate the occurrence of marine mammal hotspots and areas of high species richness. Discrepancies between a species' range and hotspot coverage serve as a gap analysis that will help identify regions and species where more research effort is required. Threats to marine mammals within identified hotspots areas are also discussed.

\section{MATERIALS AND METHODS}

\subsection{Study area}

Biotelemetry data were collected from marine mammals tagged around the Svalbard Archipelago, in the northern Barents Sea, Fram Strait and along the northeast coast of Greenland (northwards of $\left.68^{\circ} \mathrm{N}\right)$ during the last 15 years (2005-2019). The final area shown in the maps was from 58 to $90^{\circ} \mathrm{N}$ and $40^{\circ} \mathrm{W}$ to $100^{\circ} \mathrm{E}$ (Fig. 1).

The Greenland Sea (including the Fram Strait, Denmark Strait and the continental shelf of East Greenland) and the Barents Sea form the connection between the Northeast Atlantic Ocean and the Arctic Ocean (Fig. 1). The Barents Sea is moderately shallow (average depth: $230 \mathrm{~m}$; maximum depth: $\sim 500 \mathrm{~m}$ ) whereas the Greenland Sea is deeper (average depth: $1444 \mathrm{~m}$; maximum depth: $4846 \mathrm{~m}$ ). The Barents Sea is also more exposed to warm Atlantic Water than the Greenland Sea. The West Spitsbergen Current (a branch of the North Atlantic Current) flows northwards along the west coast of Svalbard, on the eastern edge of the Greenland Sea, transporting warm Atlantic Water into the Arctic Ocean (Ingvaldsen \& Loeng 2009). The East Greenland Current transports cold Arctic Water and sea ice southwards through the Fram Strait over the continental shelf of the east coast of Greenland (Rudels et al. 2002). The sea-ice maximum and minimum in this region occur in April and September, respectively (Fig. 1). The MIZ is defined as the area between the open ocean and the pack-ice with sea-ice concentrations between 15 and $80 \%$ (Fig. 1). It is a highly dynamic zone with large intra- and inter-annual variability in both its location and extent; it varies from being a few kilometres wide up to hundreds of kilometres wide. The summer productivity pulse makes the MIZ an important foraging area for many species (Sakshaug et al. 2009), including a variety of marine mammals.

\subsection{Tagging information}

Five hundred and eighty-five biotelemetry devices were deployed on animals from 13 species between 2005 and 2019 in and around Svalbard and Northeast Greenland (see Table 1, Fig. 2 and the text in the Supplement at www.int-res.com/articles/suppl/m659 p003_supp.pdf for capture and instrumentation details). The data include tags deployed on 10 species that are resident in this area throughout the year (ringed seal Pusa hispida, bearded seal Erignathus barbatus, harbour seal Phoca vitulina, walrus Odobenus rosmarus, harp seal Pagophilus groenlandicus, hooded seal Cystophora cristata, polar bear Ursus maritimus, bowhead whale Balaena mysticetus, narwhal Monodon monoceros and white whale Delphinapterus leucas) and 3 seasonally resident species (blue whale Balaenoptera musculus, fin whale Balaenoptera physalus and humpback whale Megaptera novaeangliae; see Table 1 \& Fig. 2 for more details).

Positions were calculated by the Argos satellite system (CLS 2016) or transmitted via the Argos or Iridium satellite systems (Iridium Satellite Communications) in the case of GPS data (Table 1). The single exception was walrus GPS data from Svalbard, which were transmitted to logging stations positioned at 7 terrestrial haul-out sites. All pinnipeds, except walruses, transmitted haul-out data either as the start and end times of individual haul-out events (tags produced by Sea Mammal Research Unit Instrumentation, University of St Andrews, St Andrews, Scotland) or as the proportion of time hauled out each hour (tags produced by Wildlife Computers, Redmond, WA). All tracking data from the summer of 2005 until 31 December 2018 were included in the analyses herein.

Animal handling and tagging procedures in Norwegian territories were approved by the Norwegian Animal Research Authority (before 2015) or the Norwegian Food Safety Authority (from 2015), and for animals captured in Svalbard, permits were also issued by the Governor of Svalbard. Animal handling and tagging procedures in Greenland were approved by the Greenland Institute of Natural Resources and the Government of Greenland. 


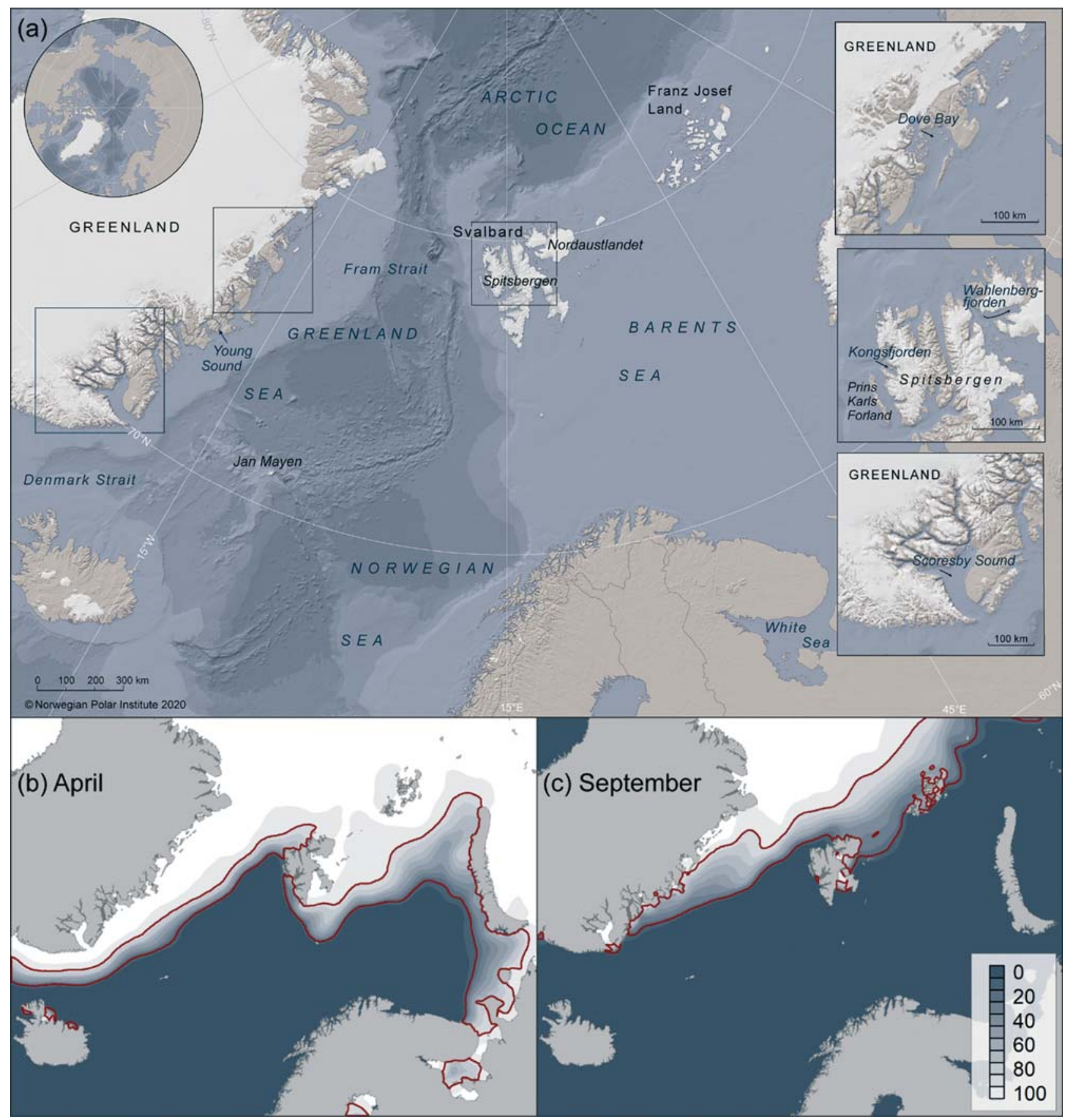

Fig. 1. Map of the study area showing (a) the major place names, ocean areas (in italic font), islands and fjords mentioned in the main text and (b,c) mean sea-ice concentrations (0-100\%) for April and September from 2005 to 2018 . The 2 red lines indicate the margins of the $15 \%$ and $80 \%$ sea-ice concentrations (i.e. they encompass the marginal ice zone). Sea-ice data were not available for some coastal areas in this region, shown in dark grey

\subsection{Location filtering}

All data handling and statistical analyses were performed using $\mathrm{R}$ version 3.5.3 (R Core Team 2019). Argos positions were filtered using the SDA filter (argosfilter package; Table S1 in the Supplement;
Freitas et al. 2008) for all species, except for walruses, blue whales, bowhead whales and fin whales. Walruses from Svalbard transmitted GPS locations and walruses from East Greenland had Argos locations that were filtered using the Douglas Argos filter (Douglas et al. 2012). SDA filter results for blue 
Table 1. Overview of the species included in the hotspot analyses including the number of tags deployed and number of animals tagged in different tagging locations, time period of tracking, seasonal coverage, age classes, tag manufacturers, position type (Argos, GPS or both) and sources (including references for published data sets) for marine mammals tagged around Svalbard and Northeast Greenland. Age classes include pups (P), sub-adults (S) and adults (A). Note: some polar bears were tagged multiple times in Svalbard; 1 ringed seal in Svalbard was also tagged 2 times. Tag manufacturers include Sea Mammal Research Unit Instrumentation (SMRU), Wildlife Computers (WC), Sirtrack, Telonics and Advanced Telemetry Systems (ATS)

\begin{tabular}{|c|c|c|c|c|c|c|c|c|c|}
\hline Species & $\begin{array}{l}\text { Tagging } \\
\text { location }\end{array}$ & $\begin{array}{l}\text { No. of } \\
\text { tags de- } \\
\text { ployed }\end{array}$ & $\begin{array}{l}\text { No. of } \\
\text { animals } \\
\text { tagged }\end{array}$ & Time period & $\begin{array}{l}\text { Seasonal } \\
\text { coverage }\end{array}$ & $\begin{array}{l}\text { Age } \\
\text { classes }\end{array}$ & s $\underset{\begin{array}{c}\text { Tag } \\
\text { manu- } \\
\text { facturer }\end{array}}{\mathrm{F}}$ & $\begin{array}{l}\text { Position } \\
\text { type }\end{array}$ & Source \\
\hline \multirow[t]{2}{*}{ Ringed seals } & Svalbard & 53 & 52 & 2010-2018 & Jul-May & $\mathrm{S} / \mathrm{A}$ & SMRU & Both & $\begin{array}{l}\text { Hamilton et al. } \\
2015,2016\end{array}$ \\
\hline & $\begin{array}{l}\text { Northeast } \\
\text { Greenland }\end{array}$ & 20 & 20 & $2017-2018$ & Aug-May & $\mathrm{S} / \mathrm{A}$ & SMRU/WC & Both & Supplement \\
\hline Bearded seals & Svalbard & 20 & 20 & $2005-2013$ & Jun-May & P/A & SMRU & Both & $\begin{array}{l}\text { Hamilton et al. } \\
2018,2019 b\end{array}$ \\
\hline Harbour seals & Svalbard & 60 & 60 & 2009-2011 & Jun-May & $\mathrm{P} / \mathrm{S} / \mathrm{A}$ & SMRU & Argos & $\begin{array}{l}\text { Blanchet et al. } \\
2014,2016\end{array}$ \\
\hline \multirow[t]{2}{*}{ Walruses } & Svalbard & 33 & 33 & 2014-2018 & Jun-May & A & Sirtrack & GPS & Supplement \\
\hline & $\begin{array}{l}\text { Northeast } \\
\text { Greenland }\end{array}$ & 18 & 18 & $2008-2010$ & Jul-Jan & A & WC & Argos & Supplement \\
\hline Harp seals & $\begin{array}{l}\text { Greenland } \\
\text { Sea }\end{array}$ & 20 & 20 & $2017-2018$ & Jun-May & $\mathrm{P}$ & SMRU/WC & Both & Supplement \\
\hline Hooded seals & $\begin{array}{l}\text { Greenland } \\
\text { Sea }\end{array}$ & 20 & 20 & $2007-2009$ & Jun-May & $\mathrm{P} / \mathrm{S} / \mathrm{A}$ & SMRU & Argos & $\begin{array}{l}\text { Vacquié-Garcia } \\
\text { et al. } 2017 \text { a }\end{array}$ \\
\hline \multirow[t]{2}{*}{ Polar bears } & Svalbard & 214 & 142 & 2005-2019 & Jun-May & \multicolumn{3}{|c|}{ Sirtrack, ATS } & Lone et al. 2018 \\
\hline & $\begin{array}{l}\text { Northeast } \\
\text { Greenland }\end{array}$ & 21 & 21 & 2007-2009 & Jun-May & S/A & Telonics & GPS & $\begin{array}{l}\text { Laidre et al. 2013, } \\
\text { 2015b }\end{array}$ \\
\hline $\begin{array}{l}\text { Bowhead } \\
\text { whales }\end{array}$ & $\begin{array}{l}\text { Greenland/ } \\
\text { Fram Strait }\end{array}$ & 23 & 23 & $\begin{array}{c}2010 \\
2017-2019\end{array}$ & Jun-May & A & WC & Argos & $\begin{array}{l}\text { Lydersen et al. 2012, } \\
\text { Kovacs et al. 2020b }\end{array}$ \\
\hline Narwhals & $\begin{array}{l}\text { Northeast } \\
\text { Greenland }\end{array}$ & 39 & 39 & $2010-2017$ & Jun-May & A & WC & Both & $\begin{array}{l}\text { Heide-Jørgensen } \\
\text { et al. } 2015\end{array}$ \\
\hline White whales & Svalbard & 18 & 18 & 2013-2017 & Jul-Feb & A & SMRU & Argos & $\begin{array}{l}\text { Vacquié-Garcia et } \\
\text { al. } 2018\end{array}$ \\
\hline Blue whales & Svalbard & 10 & 10 & 2014-2018 & Aug-Dec & A & WC & Argos & Supplement \\
\hline Fin whales & Svalbard & 6 & 6 & 2015-2018 & Sep-Dec & A & WC & Argos & Supplement \\
\hline $\begin{array}{l}\text { Humpback } \\
\text { whales }\end{array}$ & Barents Sea & a 10 & 10 & 2018-2019 & Sep-Dec & A & WC & Argos & Supplement \\
\hline \multicolumn{2}{|c|}{ Total (13 species) } & 585 & 512 & 2005-2019 & Jun-May & & & & \\
\hline
\end{tabular}

whales, bowhead whales and fin whales were deemed to be too conservative, despite trying different maximum movement speeds and turning angles, so locations for these 3 species were filtered by removing quality Z locations (i.e. invalid locations) and manually removing large location spikes resulting from Argos error. All species and location types (Argos and GPS) were subsequently filtered using the continuous-time correlated random walk model (CTCRW model, crawl package; Johnson et al. 2008) with a stopping model incorporated to account for time spent hauled out for all pinnipeds except walruses. Locations every second hour were interpolated from the CTCRW model for each animal. Interpolated locations that occurred during gaps in transmitted locations over $5 \mathrm{~d}$ long were removed from the dataset. The narwhal data had duty cycles of varying lengths beginning in either September or October (see Heide-Jørgensen et al. 2015 for details); locations were used only from days when transmissions occurred.

A land shapefile for the NE Atlantic was made by combining 3 sources: (1) the Global Self-consistent, Hierarchical, High-resolution Geography Database (GSHHG) full-resolution coastline shapefile (version 2.3.7; Wessel \& Smith 1996); (2) a coastline shapefile for Svalbard (Norwegian Polar Institute; www.npolar .no); and (3) a coastline shapefile for Greenland (Danish Geodata Agency; www.eng.gst.dk). On-land locations were moved to the closest 'in water' loca- 


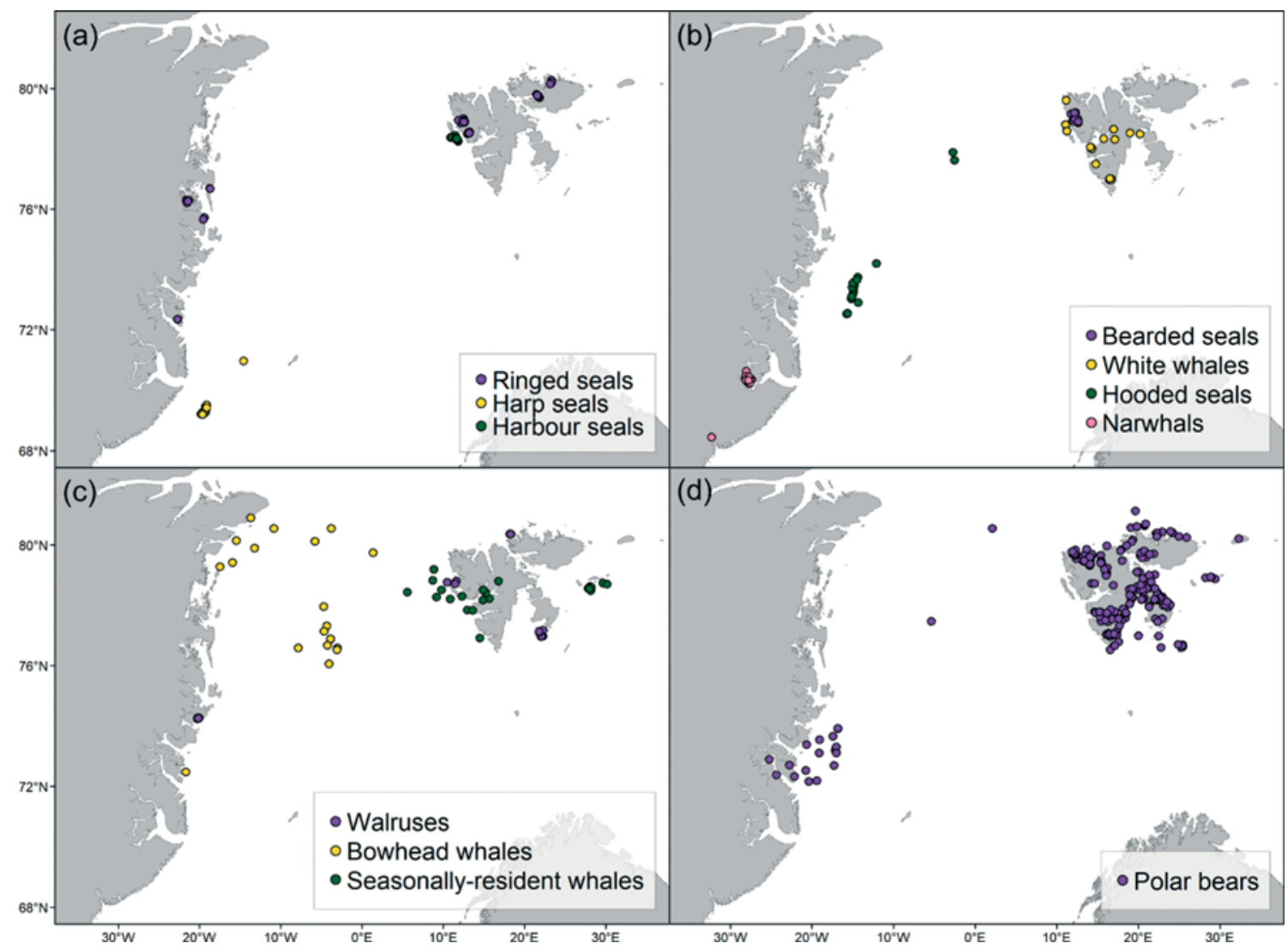

Fig. 2. Capture locations for 13 marine mammal species (including 3 seasonally resident whale species) used in the analysis of marine mammal hotspots in the Greenland and northern Barents Seas. (a) Ringed seals, harp seals and harbour seals; (b) bearded seals, white whales, hooded seals and narwhals; (c) walruses, bowhead whales and seasonally-resident whales; (d) polar bears

tion (in time) for each individual (except for polar bears). Locations were subsequently rasterized into a $10 \times 10 \mathrm{~km}$ grid, and the number of individuals of each species (individual hotspots analysis), the number of locations for each species (location hotspots analysis) and the number of species (species richness) in each grid cell were calculated. A $10 \times 10 \mathrm{~km}$ grid was chosen as a compromise between showing large-scale patterns across the Greenland and Barents Seas and showing patterns within small fjords in Svalbard and Greenland (e.g. Kongsfjorden, a fjord in Svalbard with high tagging effort, is $\sim 5 \times 20 \mathrm{~km}$ ).

\subsection{Marine mammal hotspots}

Marine mammal hotspots were calculated in order to identify areas that are heavily used by different marine mammal species in the Greenland and northern Barents Seas. Hotspot analyses were run for the whole year as well as for summer/autumn (Jun-Dec) and winter/spring (Jan-May) periods to account for intra-annual variation in sea-ice extent (Fig. 1) and species' movement and behaviour patterns on a seasonal basis. Various hotspot methods were explored including the percent volume method (Citta et al. 2018), the lattice-based density estimator (Barry \& McIntyre 2011), the kernel home range method (package adehabitatHR; Calenge 2006) and the Getis-Ord $G_{i}{ }^{*}$ method (Getis \& Ord 1992, Ord \& Getis 1995). The Getis-Ord $G_{i}{ }^{*}$ method was chosen because it includes values of neighbouring points, has a rapid computational run time and excludes land areas.

Individual and location hotspots, based on the number of individuals and locations in grid cells, were calculated using the Getis-Ord $G_{i}{ }^{*}$ statistic (Getis \& Ord 1992; e.g. Queiroz et al. 2016, Yurkowski et al. 2019). The Getis-Ord $G_{i}^{*}$ statistic identifies local spatial patterns in a dataset by measuring the concentration of a variable around a point. It compares the local sum of values within a specified distance of a point (i.e. a point and its neighbours) to an expected local sum (drawn without replacement from all points in the dataset). If the calculated local 
sum is larger than the expected local sum, and the difference is too large to be the result of random chance, a statistically significant positive $z$-score is assigned to that point (Getis \& Ord 1992, Ord \& Getis 1995). Individual hotspots identify areas used by the majority of the tagged animals, while location hotspots identify areas heavily used, sometimes by only a small portion of the tagged animals.

All individuals and locations were given equal weighting in the hotspot analysis conducted for each species. The equal-weighting option was chosen to avoid relying on potentially erroneous assumptions about the representativeness of the data in different locations and time intervals. Ringed seal, walrus and polar bear hotspots were calculated separately for animals tagged in Svalbard and Northeast Greenland due to these areas having separate populations; sample sizes also differed in the 2 areas (see Figs. S1-S3 in the Supplement for hotspot results when analyses were run for Svalbard and Northeast Greenland combined). For the 'all species' hotspot analysis, each species was given an equal weight when calculating the number of individuals and locations in each grid cell. The localG function in the spdep package (Bivand \& Wong 2018) was used to calculate the Getis-Ord $G_{i}{ }^{*}$ statistic. The number of neighbours for each grid cell was defined as the number of grid cells within the distance that maximized spatial autocorrelation for each species, found by calculating the global Getis-Ord $G_{i}{ }^{*}$ statistic in $10 \mathrm{~km}$ increments from 10 to $200 \mathrm{~km}$ (globalG.test function in spdep package, Table S2 in the Supplement; Ord \& Getis 1995, Bivand \& Wong 2018).
Four hotspot levels were plotted: $99 \%(z \geq 2.58, \mathrm{p} \leq$ $0.01), 95 \%(z \geq 1.96, p \leq 0.05), 90 \%(z \geq 1.65, p \leq 0.1)$ and $70 \%(z \geq 1.15, p \leq 0.3)$, following Getis \& Ord (1992). Low-use areas $(z<1.15, p>0.3)$ were plotted as a continuous polygon that encompassed all areas used by each species. Coldspots (i.e. areas with significant negative autocorrelation) were not plotted as they indicate areas infrequently used by tracked animals, not necessarily areas infrequently used by the species. The range for each species was downloaded from the International Union for the Conservation of Nature (IUCN) Red List of Threatened Species (IUCN 2020) and plotted to show the hotspots in the context of where each species is likely to be found in the study area. The amount of overlap between high hotspot levels (i.e. $95 \%$ and $99 \%$ ) and high levels of species richness ( $\geq 4$ species for annual and summer/autumn, $\geq 2$ species for winter/spring) was also calculated.

Null models were created for the Getis-Ord $G_{i}{ }^{*}$ statistic for each species and all species combined to represent where individual and location hotspots would be expected given the tagging locations and movement patterns of each species (see Queiroz et al. 2016, Yurkowski et al. 2019). The basis for the null models comprised simulated correlated random walks created for each species using Weibell distributed step lengths and Von Mises distributed turning angles. The step lengths and turning angles for each species were used to create the relevant distributions for the simulated tracks. The maximum step length for each species was used to set an upper limit on the step lengths

Table 2. Total, mean $( \pm \mathrm{SD})$ and maximum tracking duration $(\mathrm{d})$ and the month of tagging for animals in each of the 13 marine mammal species tagged around Svalbard and Northeast Greenland

\begin{tabular}{|lcccl|}
\hline Species & $\begin{array}{c}\text { Total tracking } \\
\text { duration }(\mathrm{d})\end{array}$ & $\begin{array}{c}\text { Tracking duration } \\
\left(\mathrm{d}_{i} \text { mean } \pm \text { SD }\right)\end{array}$ & $\begin{array}{c}\text { Maximum tracking } \\
\text { duration }(\mathrm{d})\end{array}$ & Tagging month \\
\hline Ringed seals & 12452 & $171 \pm 66$ & 305 & $\begin{array}{l}\text { Jul-Aug } \\
\text { Pups: May } \\
\text { Bearded seals }\end{array}$ \\
& 3625 & $181 \pm 106$ & 367 & $\begin{array}{l}\text { Pdults: Jul-Aug } \\
\text { Sub- Jun-Jul }\end{array}$ \\
Harbour seals & 11369 & $189 \pm 107$ & 392 & Jul-Aug \\
Walruses & 12033 & $236 \pm 351$ & 1485 & Apr \\
Harp seals & 3559 & $178 \pm 143$ & 400 & Mar \& Jul \\
Hooded seals & 3280 & $164 \pm 128$ & 424 & Mar-Apr \& Aug \\
Polar bears & 72710 & $309 \pm 236$ & 1192 & Jun \& Sep \\
Bowhead whales & 3164 & $144 \pm 152$ & 613 & Aug-Sep \\
Narwhals & 5577 & $143 \pm 88$ & 420 & Jul-Aug \\
White whales & 1585 & $88 \pm 59$ & 191 & Aug-Oct \\
Blue whales & 244 & $27 \pm 19$ & 61 & Sep \\
Fin whales & 193 & $32 \pm 22$ & 64 & Sep \\
Humpback whales & 894 & $89 \pm 31$ & 118 & \\
\hline
\end{tabular}




\section{RINGED SEALS}

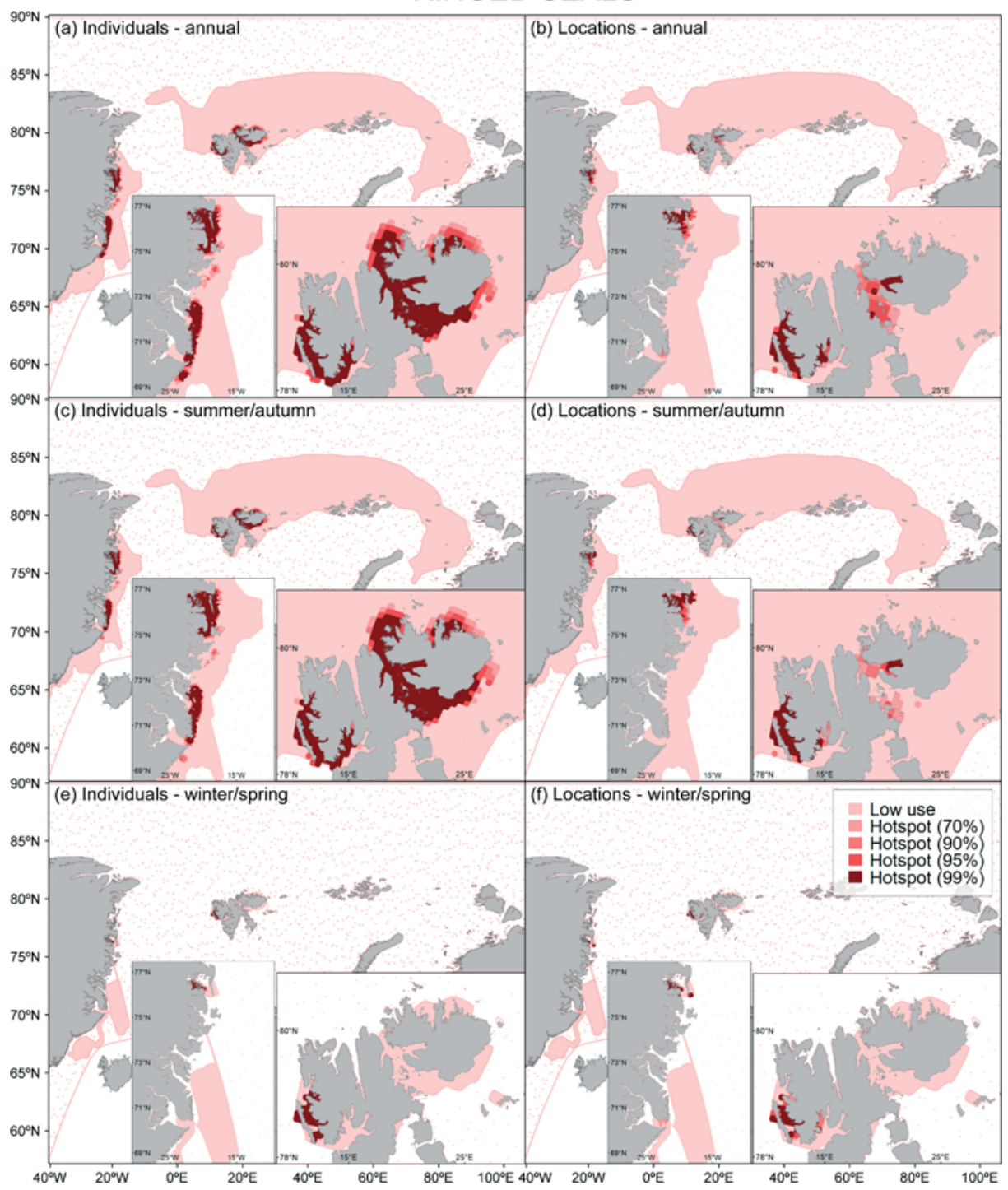

Fig. 3. Getis-Ord $G_{i}^{*}(\mathrm{a}, \mathrm{c}, \mathrm{e})$ individual hotspots and $(\mathrm{b}, \mathrm{d}, \mathrm{f})$ location hotspots for 73 ringed seals tagged in Svalbard and Northeast Greenland over $(a, b)$ the entire year, $(c, d)$ during the summer/autumn and $(e, f)$ during the winter/spring. Inset maps show hotspots in East Greenland (left) and northern Svalbard (right). Increasing intensities of red indicate hotspots of different levels of statistical significance; the pink dotted polygon shows the species' range. The analysis was run for ringed seals tagged in Svalbard and Northeast Greenland separately

selected for the simulations. One correlated random walk was simulated for each individual in each species; the simulated track had the same starting location and the same number of steps as the individual's observed track. The simulated tracks for each species (except for polar bears) were constrained to the ocean. A null model for species richness was also made from the simulated correlated random walks. The amount of overlap between high marine mammal hotspot levels and high null model hotspot levels (i.e. 95\% and 99\%) was also calculated.

\section{RESULTS}

\subsection{Species distributions}

3.1.1. Ringed seals Pusa hispida. Ringed seals mainly occupied coastal areas in Northeast Greenland and Svalbard (Fig. 3, Tables 1 \& 2), though some ringed seals from Svalbard took trips offshore in the summer and autumn, ranging as far east as the Kara Sea and as far north as the Arctic Ocean north of the Fram Strait. Some of the ringed seals from Northeast Greenland also used offshore areas on the East 


\section{BEARDED SEALS}

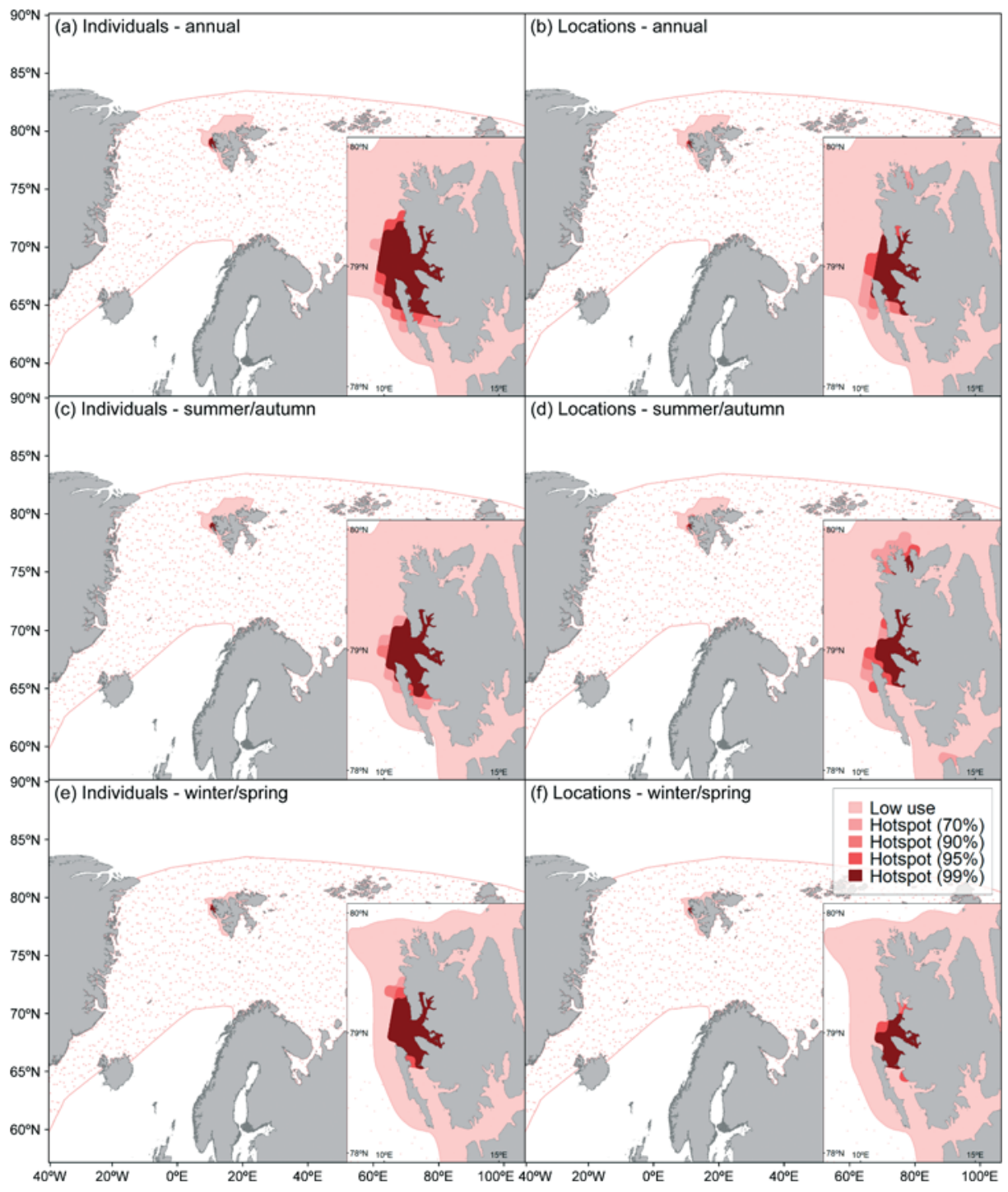

Fig. 4. Getis-Ord $G_{i}^{*}(\mathrm{a}, \mathrm{c}, \mathrm{e})$ individual hotspots and $(\mathrm{b}, \mathrm{d}, \mathrm{f})$ location hotspots for 20 bearded seals tagged in Svalbard over $(\mathrm{a}, \mathrm{b})$ the entire year, $(\mathrm{c}, \mathrm{d})$ during the summer/autumn and $(\mathrm{e}, \mathrm{f})$ during the winter/spring. Inset maps show hotspots in northwestern Svalbard. Details as in Fig. 3 legend

Greenland continental shelf. Ringed seals had wider distributions in the summer/autumn than in the winter/spring (Fig. 3). Hotspots (both individual and location) were found in coastal regions of Svalbard and Northeast Greenland (Fig. 3). Null model hotspots for ringed seals were in northwestern Svalbard, in Wahlenbergfjorden (a fjord in Nordaustlandet, NE Svalbard) and in Dove Bay (Greenland), in the vicinities where tagging took place for this species (Fig. 2a, Fig. S4a,b in the Supplement). Highly significant null model hotspot levels (95\% and $99 \%$ ) overlapped ringed seal hotspots (95\% and $99 \%$ ) by $21 \%$ and $59 \%$ for individual and location hotspots, respectively (Table 3 ).
3.1.2. Bearded seals Erignathus barbatus. Bearded seals were located in shallow areas along the western and northern coasts of Svalbard and hotspots (both individual and location) were located in north-western Svalbard (Fig. 4, Tables 1 \& 2). Null model hotspots for bearded seals were also located in north-western Svalbard, near the area where the animals were tagged (Figs. 2b, S4c,d). Highly significant null model hotspot levels (95\% and $99 \%$ ) overlapped bearded seal hotspots (95\% and $99 \%$ ) by $81 \%$ and $90 \%$ for individual and location hotspots, respectively (Table 3 ).

3.1.3. Harbour seals Phoca vitulina. Harbour seals were located mainly in western Svalbard, both in 


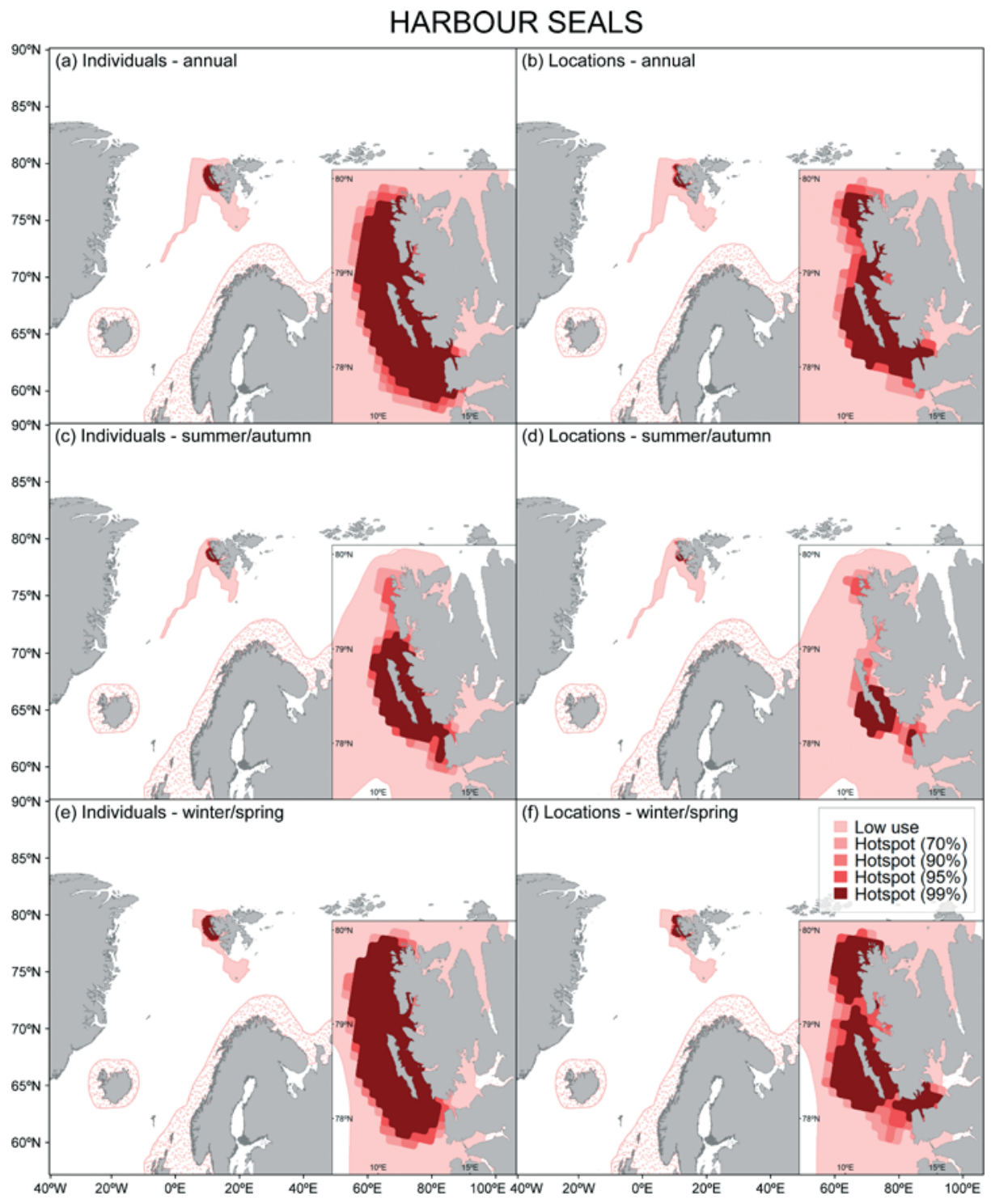

Fig. 5. Getis-Ord $G_{i}^{*}(\mathrm{a}, \mathrm{c}, \mathrm{e})$ individual hotspots and $(\mathrm{b}, \mathrm{d}, \mathrm{f})$ location hotspots for 60 harbour seals tagged in Svalbard over $(\mathrm{a}, \mathrm{b})$ the entire year, $(\mathrm{c}, \mathrm{d})$ during the summer/autumn and $(\mathrm{e}, \mathrm{f})$ during the winter/spring. Inset maps show hotspots in northwestern Svalbard. Details as in Fig. 3 legend

coastal areas and over the continental shelf. Some harbour seals travelled to northern Svalbard and south as far as Bjørnøya (Fig. 5, Tables 1 \& 2). Hotspots (both individual and location) were located in north-western Svalbard. Individual hotspots and winter/spring hotspots covered a larger area than location hotspots and summer/autumn hotspots (Fig. 5). Null model hotspots for harbour seals were located in western Svalbard, west of their tagging area in Forlandsøyene, just west of Prins Karls Forland (Fig. 2a, Fig. S4e,f in the Supplement). Highly significant null model hotspot levels (95\% and 99\%) overlapped harbour seal hotspots ( $95 \%$ and $99 \%$ ) by
$65 \%$ and $60 \%$ for individual and location hotspots, respectively (Table 3 ).

3.1.4. Walruses Odobenus rosmarus. Walruses were located in coastal areas of Northeast Greenland and in the northern Barents Sea. Hotspots (both individual and location) were located along the northeastern coast of Greenland between 74 and $81^{\circ} \mathrm{N}$, in southern and northern Svalbard, and in Russian waters between Svalbard and Franz Josef Land (Fig. 6, Tables 1 \& 2). Individual hotspots covered a wider geographical area than location hotspots (Fig. 6). Location hotspots were also located in Northeast Greenland (i.e. in the Northeast Water Polynya) 


\section{WALRUSES}

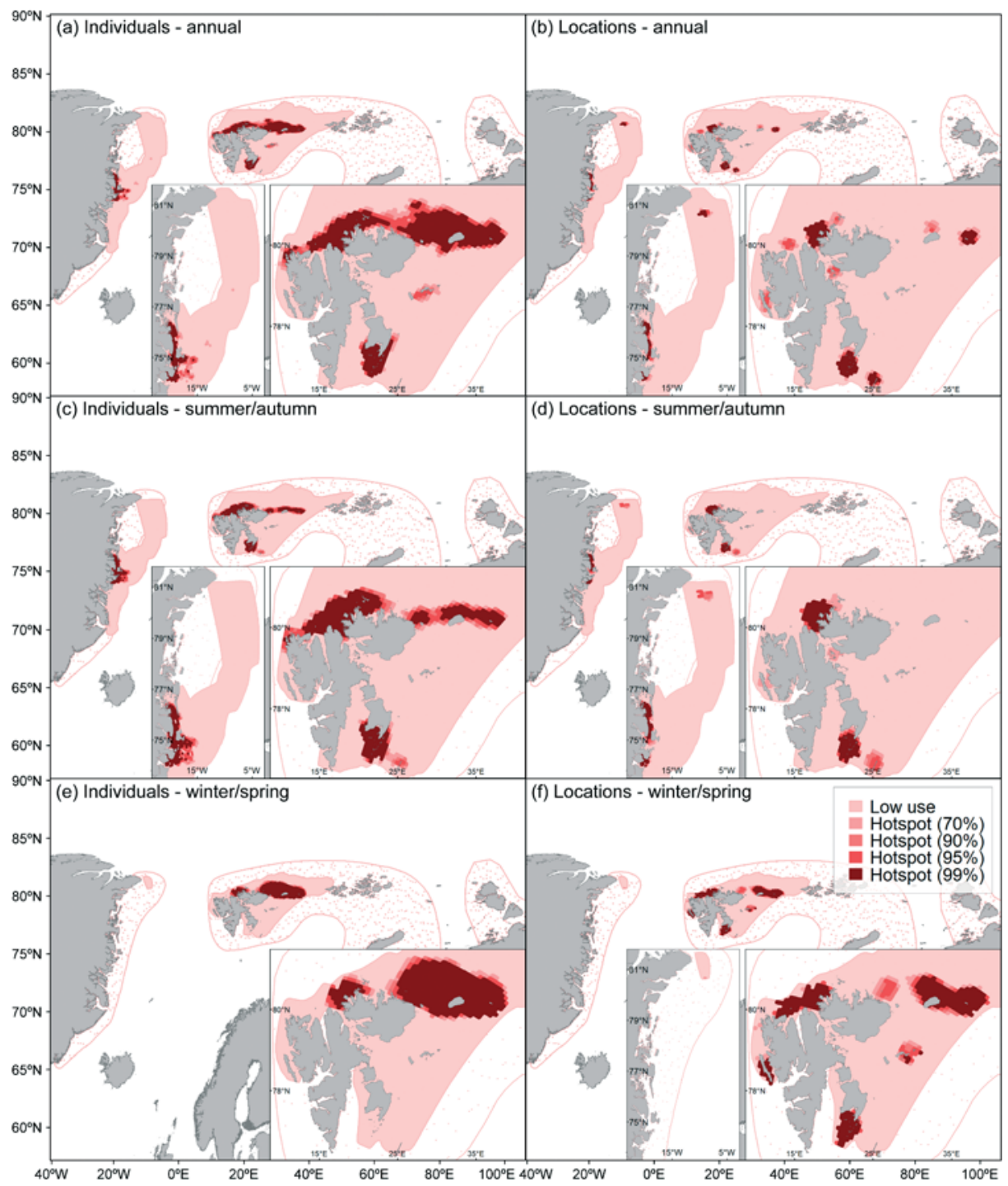

Fig. 6. Getis-Ord $G_{i}^{*}(\mathrm{a}, \mathrm{c}, \mathrm{e})$ individual hotspots and $(\mathrm{b}, \mathrm{d}, \mathrm{f})$ location hotspots for 51 walruses tagged in Svalbard and Northeast Greenland over $(a, b)$ the entire year, $(c, d)$ during the summer/autumn and $(e, f)$ during the winter/spring. Inset maps show hotspots in East Greenland (left) and Svalbard (right). There were no individual hotspots during the winter/spring for walruses tagged in East Greenland. Details as in Fig. 3 legend. The analysis was run for walruses tagged in Svalbard and Northeast Greenland separately

Table 3. Amount (\%) that null models of Getis-Ord $G_{i}^{*}$ hotspots (95\% and $\left.99 \%\right)$ overlapped hotspots $(95 \%$ and $99 \%)$ made from tracks of 13 marine mammals (including 3 seasonally resident whale species) in the Greenland and Barents Seas

\begin{tabular}{|c|c|c|c|c|c|}
\hline \multirow[b]{2}{*}{ Species } & \multicolumn{2}{|c|}{ Overlap (\%) } & \multirow[b]{2}{*}{ Species } & \multicolumn{2}{|c|}{ Overlap (\%) } \\
\hline & $\begin{array}{c}\text { Individual } \\
\text { hotspots }\end{array}$ & $\begin{array}{l}\text { Location } \\
\text { hotspots }\end{array}$ & & $\begin{array}{c}\text { Individual } \\
\text { hotspots }\end{array}$ & $\begin{array}{l}\text { Location } \\
\text { hotspots }\end{array}$ \\
\hline Ringed seals & 21 & 59 & Polar bears & 31 & 70 \\
\hline Bearded seals & 81 & 90 & Bowhead whales & 5 & 2 \\
\hline Harbour seals & 65 & 60 & Narwhals & 43 & 34 \\
\hline Walruses & 20 & 39 & White whales & 13 & 9 \\
\hline Harp seals & 18 & 9 & Seasonally resident whales & 26 & 29 \\
\hline Hooded seals & 20 & 18 & All species & 30 & 34 \\
\hline
\end{tabular}




\section{HARP SEALS}

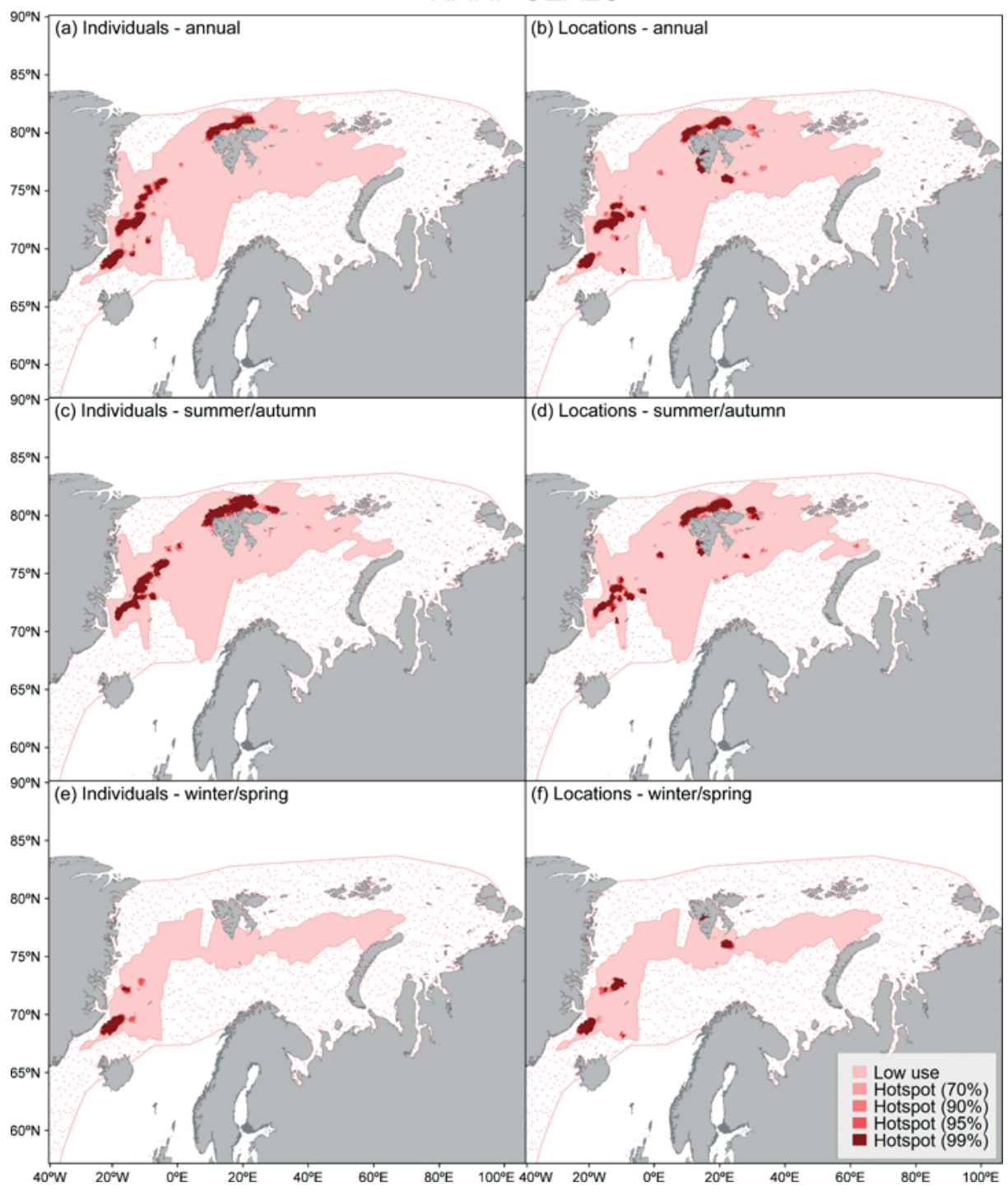

Fig. 7. Getis-Ord $G_{i}^{*}(\mathrm{a}, \mathrm{c}, \mathrm{e})$ individual hotspots and $(\mathrm{b}, \mathrm{d}, \mathrm{f})$ location hotspots for 20 harp seals tagged in the Greenland Sea over $(a, b)$ the entire year, $(c, d)$ during the summer/autumn and $(e, f)$ during the winter/spring. Details as in Fig. 3 legend

in the summer/autumn, in western Svalbard in the winter/spring and covered a wider distributional area in the winter/spring around the Svalbard Archipelago than in the summer/autumn (Fig. 6). A lack of hotspots for walruses in Northeast Greenland in the winter/spring is due to only 2 of the 18 walruses transmitting location data after December, with both of these data streams terminating in January. Null model hotspots for walruses were mainly situated around northern and south-eastern Svalbard and around Young Sound in East Greenland, near the area where the walruses were tagged (Fig. 2c, Fig. S5a,b in the Supplement). Highly significant null model hotspot levels (95\% and 99\%) overlapped walrus hotspots (95\% and $99 \%$ ) by $20 \%$ and $39 \%$ for individual and location hotspots, respectively (Table 3).

3.1.5. Harp seals Pagophilus groenlandicus. Harp seals occupied the Greenland Sea and the northern Barents Sea (Fig. 7, Tables 1 \& 2). Hotspots (both individual and location) were concentrated in the MIZ in the Greenland Sea and in northern Svalbard. Location hotspots were also found in western and southern Svalbard (Fig. 7). Summer/autumn hotspots covered a larger area in the Barents Sea than winter/spring hotspots. Null model hotspots for harp 


\section{HOODED SEALS}

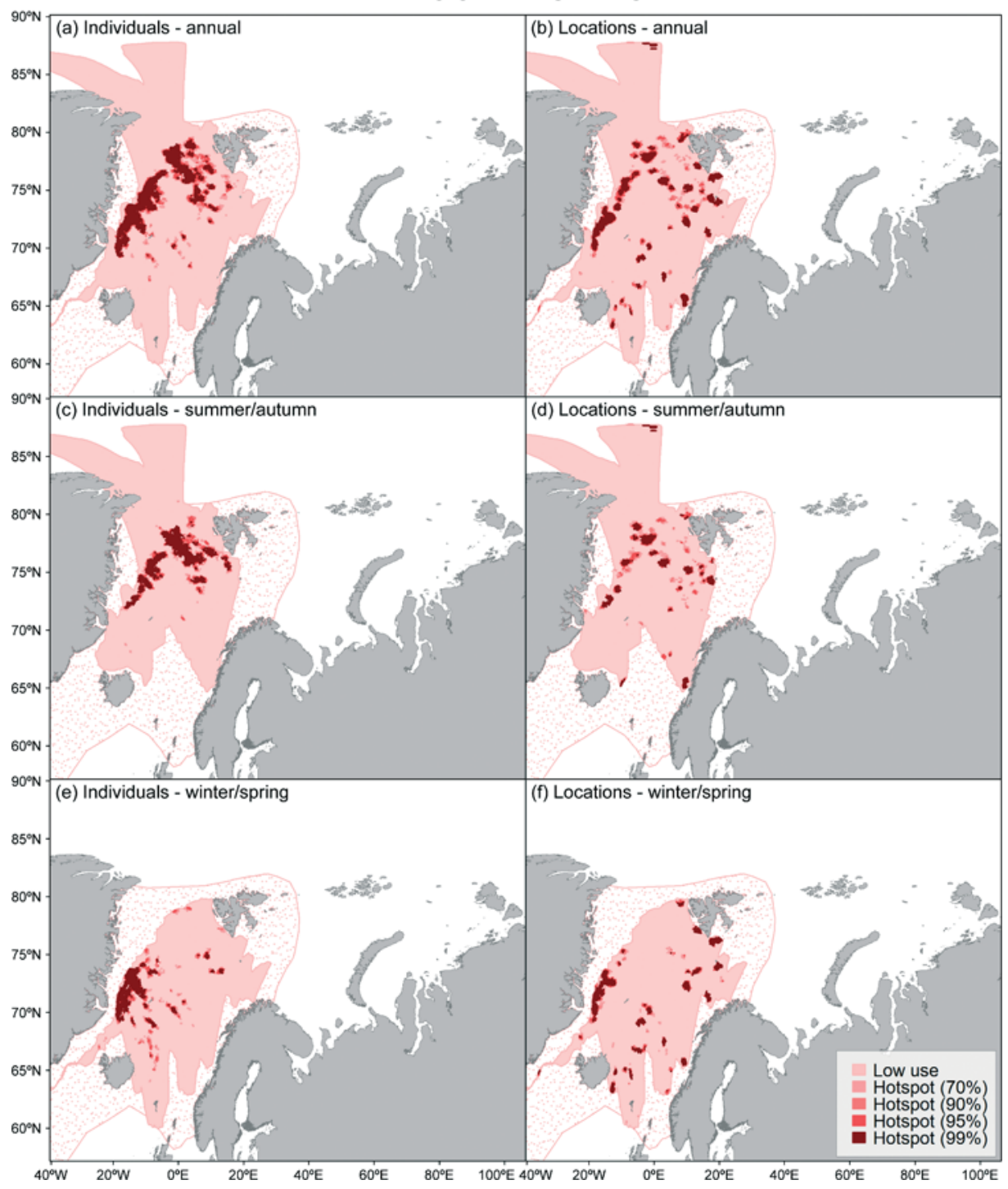

Fig. 8. Getis-Ord $G_{i}^{*}(\mathrm{a}, \mathrm{c}, \mathrm{e})$ individual hotspots and (b,d,f) location hotspots for 20 hooded seals tagged in the Greenland Sea over $(a, b)$ the entire year, $(c, d)$ during the summer/autumn and $(e, f)$ during the winter/spring. Details as in Fig. 3 legend

seals were situated in the Greenland Sea near the areas where they had been tagged (Fig. 2a, Fig. S5c,d in the Supplement). Highly significant null model hotspot levels (95\% and 99\%) overlapped harp seal hotspots (95\% and $99 \%$ ) by $18 \%$ and $9 \%$ for individual and location hotspots, respectively (Table 3).

3.1.6. Hooded seals Cystophora cristata. Hooded seals were mainly located in the Greenland Sea and off the west coast of Svalbard (Fig. 8, Tables 1 \& 2). Hotspots (both individual and location) were mainly in the deep areas of the Greenland Sea. Location hotspots were also found on the continental shelf west and south of Svalbard and close to the Norwegian coast (Fig. 8). Null model hotspots for hooded seals were located in the Greenland Sea in the vicinity of where they had been tagged (Fig. 2b, Fig. S5e,f in the Supplement). Highly significant null model hotspot levels (95\% and 99\%) overlapped hooded seal hotspots ( $95 \%$ and $99 \%$ ) by $20 \%$ and $18 \%$ for individual and location hotspots, respectively (Table 3).

3.1.7. Polar bears Ursus maritimus. Polar bears were found in the Greenland Sea, northern Barents Sea and Arctic Ocean (Fig. 9, Tables 1 \& 2). Hotspots (both individual and location) were found in coastal 


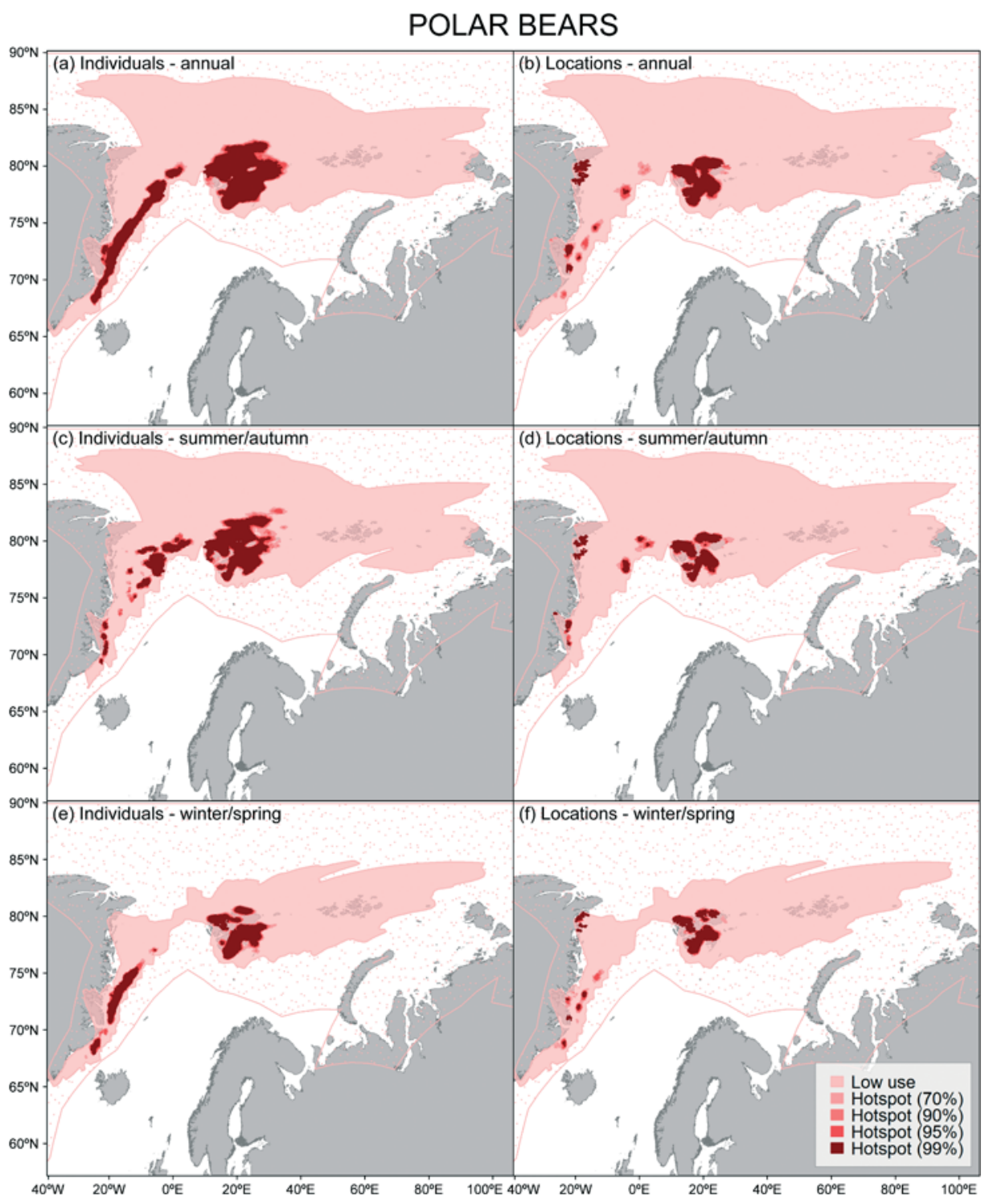

Fig. 9. Getis-Ord $G_{i}^{*}(\mathrm{a}, \mathrm{c}, \mathrm{e})$ individual hotspots and $(\mathrm{b}, \mathrm{d}, \mathrm{f})$ location hotspots for 235 polar bears tagged around Svalbard and Northeast Greenland over $(\mathrm{a}, \mathrm{b})$ the entire year, $(\mathrm{c}, \mathrm{d})$ during the summer/autumn and $(\mathrm{e}, \mathrm{f})$ during the winter/spring. Details as in Fig. 3 legend. The analysis was run for bears tagged in Svalbard and Northeast Greenland separately

and offshore areas of Northeast Greenland and around the Svalbard Archipelago (Fig. 9). Most of the coastal hotspots in Northeast Greenland corresponded to denning locations identified in Laidre et al. (2015b). Summer-autumn hotspots covered a wider area around the Svalbard Archipelago and were found further north in the MIZ in the Greenland Sea compared to winter/spring hotspots (Fig. 9). Note that most of the biotelemetry data from Northeast Greenland were from bears tagged in offshore areas; of the 21 bears tagged in 2007 and 2008, only 5 were instrumented on coastal land-fast ice in fjords. Many polar bears in Northeast Greenland reside year-round in coastal regions and show strong site fidelity (Boertmann \& Mosbech 2012, Laidre et al. 2015b, 2018). Null model hotspots for polar bears were situated around the Svalbard Archipelago and in the Greenland Sea (Fig. 2d, Fig. S6a,b in the Supplement). Highly significant null model hotspot levels $(95 \%$ and $99 \%$ ) overlapped polar bear hotspots (95\% and $99 \%$ ) by $31 \%$ and $70 \%$ for individual and location hotspots, respectively (Table 3 ).

3.1.8. Bowhead whales Balaena mysticetus. Bowhead whales were located mainly in the northern Barents and Greenland Seas, within the MIZ (Fig. 10, Tables 1 \& 2). Hotspots were located in Northeast 


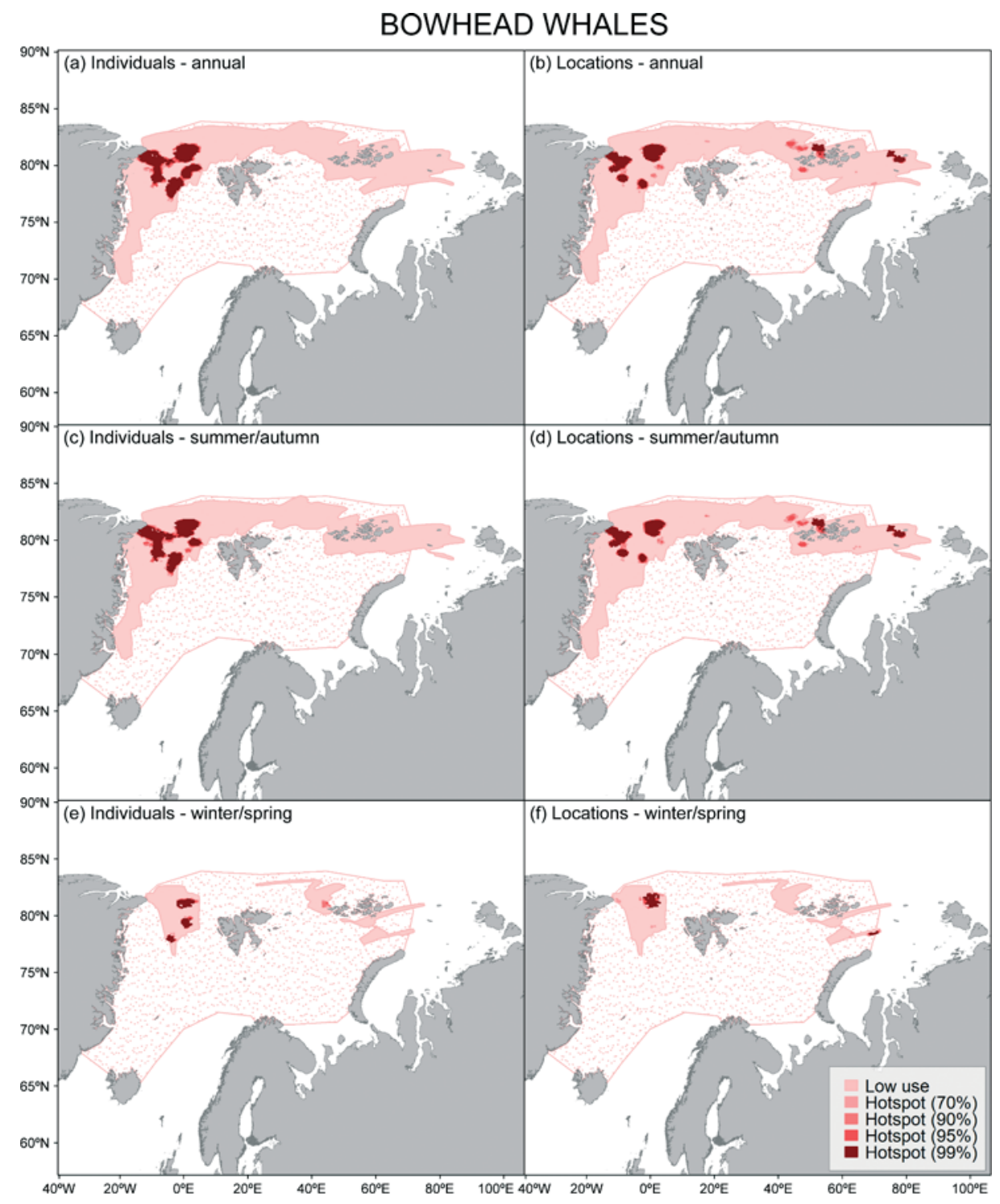

Fig. 10. Getis-Ord $G_{i}^{*}(\mathrm{a}, \mathrm{c}, \mathrm{e})$ individual hotspots and $(\mathrm{b}, \mathrm{d}, \mathrm{f})$ location hotspots for 22 bowhead whales tagged in the marginal ice zone in the Fram Strait and off of north-eastern Greenland over $(a, b)$ the entire year, $(c, d)$ during the summer/autumn and $(\mathrm{e}, \mathrm{f})$ during the winter/spring. Details as in Fig. 3 legend

Greenland (both individual and location hotspots) and around Franz Josef Land (mainly location hotspots; Fig. 10). Summer/autumn hotspots covered a larger geographical area than winter/spring hotspots (Fig. 10). Null model hotspots for bowheads were found in Northeast Greenland and in the Fram Strait (Fig. 2c, Fig. S6c,d in the Supplement). Highly significant null model hotspot levels (95\% and 99\%) overlapped bowhead whale hotspots (95\% and $99 \%$ ) by $5 \%$ and $2 \%$ for individual and location hotspots, respectively (Table 3 ).

3.1.9. Narwhals Monodon monoceros. Narwhal hotspots (both individual and location) were found within Scoresby Sound (summer hotspots) and at the edge of the continental shelf outside of the fjord (winter hotspots) (Fig. 11, Tables $1 \&$ 2). Null model hotspots for narwhals were found in Scoresby Sound, the main area where the animals had been tagged (Fig. 2b, Fig. S6e, fin the Supplement). Highly significant null model hotspot levels (95\% and $99 \%$ ) overlapped narwhal hotspots (95\% and $99 \%$ ) by $43 \%$ and $34 \%$ for individual and location hotspots, respectively (Table 3).

3.1.10. White whales Delphinapterus leucas. White whales were found in coastal regions of Svalbard (Fig. 12, Tables 1 \& 2). Hotspots (both individual 


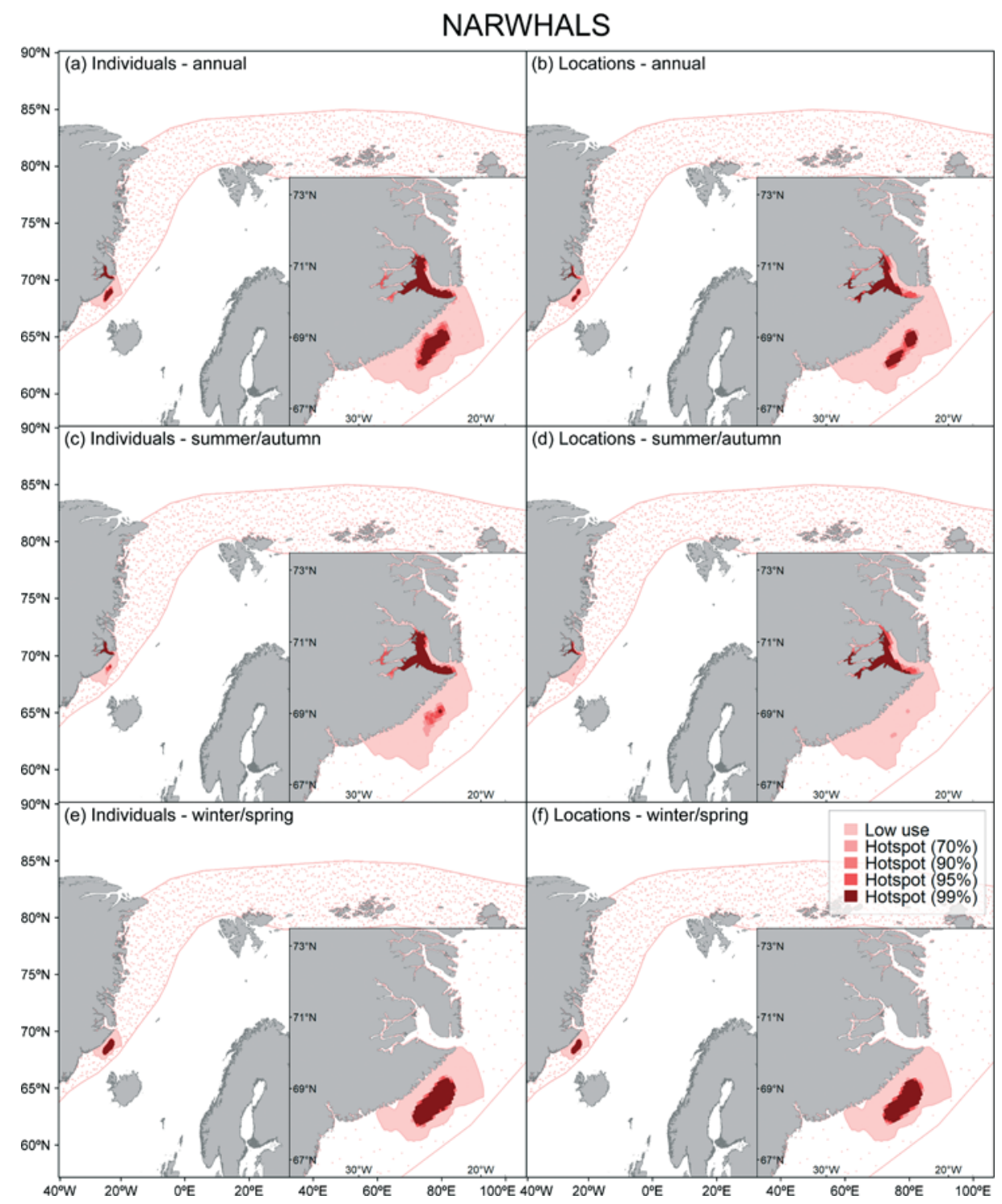

Fig. 11. Getis-Ord $G_{i}^{*}(\mathrm{a}, \mathrm{c}, \mathrm{e})$ individual hotspots and $(\mathrm{b}, \mathrm{d}, \mathrm{f})$ location hotspots for 39 narwhals tagged in Northeast Greenland over $(\mathrm{a}, \mathrm{b})$ the entire year, $(\mathrm{c}, \mathrm{d})$ during the summer/autumn and $(\mathrm{e}, \mathrm{f})$ during the winter/spring. Inset maps show hotspots in Northeast Greenland. Details as in Fig. 3 legend

and location) were found in both south-eastern and south-western Svalbard (Fig. 12). Location hotspots were also found in northern Svalbard fjords (Fig. 12). Null model hotspots for white whales were in western Svalbard, extending over the continental shelf break into the Greenland Sea (Fig. 2b, Fig. S7a,b in the Supplement). Highly significant null model hotspot levels (95\% and 99\%) overlapped white whale hotspots (95\% and $99 \%$ ) by $13 \%$ and $9 \%$ for individual and location hotspots, respectively (Table 3).

3.1.11. Seasonally resident whales. Seasonally resident whales were found in the Barents Sea, Greenland Sea and Norwegian Sea (Fig. 13, Tables 1 \& 2).
Hotspots were located around the Svalbard Archipelago and near Jan Mayen (Fig. 13). Location hotspots were also found within Svalbard fjords, while individual hotspots were found mainly in coastal areas (Fig. 13). Null model hotspots for seasonally resident whales were found in western Svalbard and south-east of Nordaustlandet, near the areas where these species had been tagged (Fig. 2C, Fig. $\mathrm{S}_{\mathrm{c}} \mathrm{d}$ d in the Supplement). Highly significant null model hotspot levels $(95 \%$ and $99 \%)$ overlapped seasonally resident whale hotspots (95\% and $99 \%$ ) by $26 \%$ and $29 \%$ for individual and location hotspots, respectively (Table 3 ). 


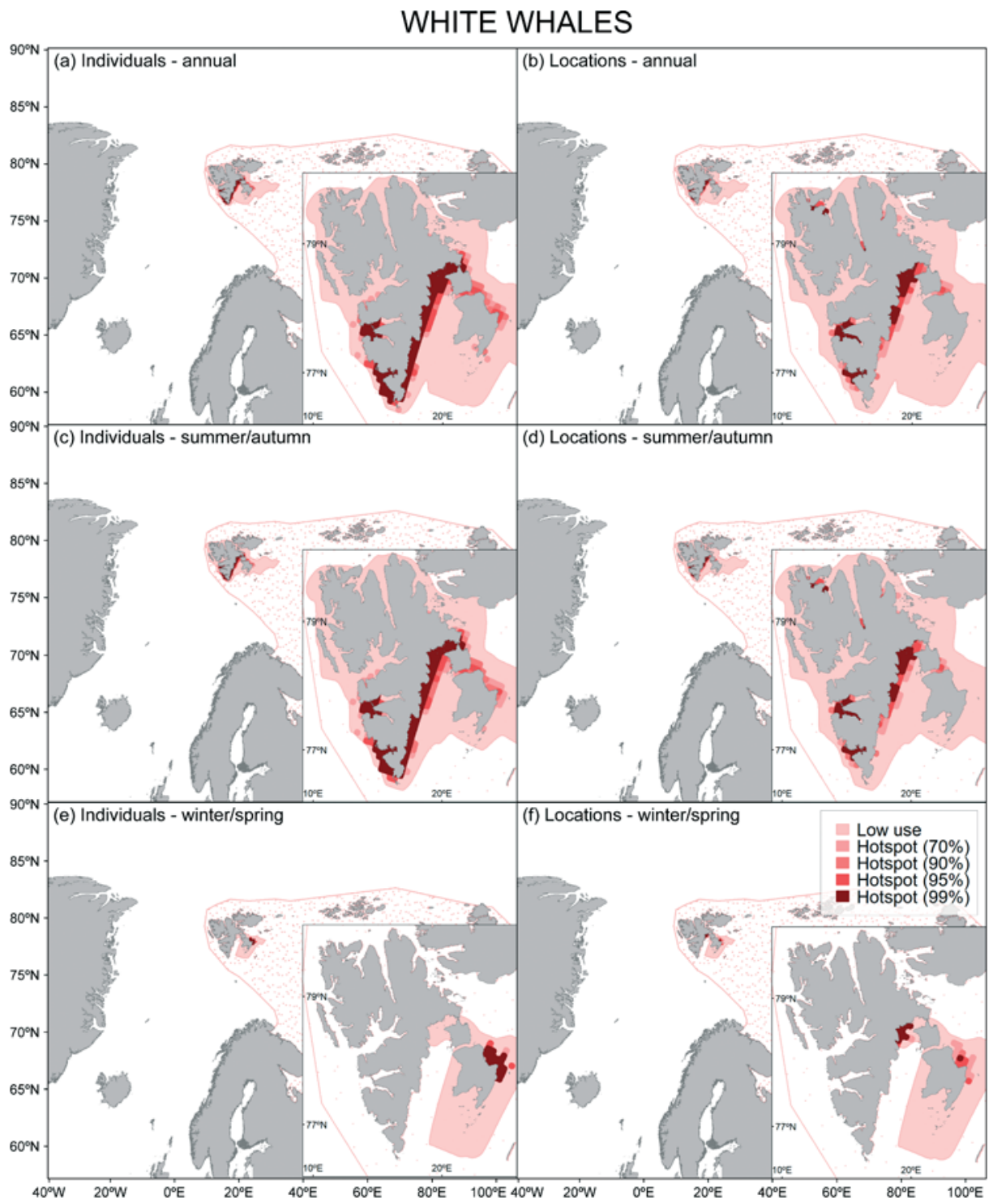

Fig. 12. Getis-Ord $G_{i}^{*}(\mathrm{a}, \mathrm{c}, \mathrm{e})$ individual hotspots and $(\mathrm{b}, \mathrm{d}, \mathrm{f})$ location hotspots for 18 white whales tagged in Svalbard over $(a, b)$ the entire year, $(c, d)$ during the summer/autumn and $(e, f)$ during the winter/spring. Inset maps show hotspots around the Svalbard Archipelago. Details as in Fig. 3 legend

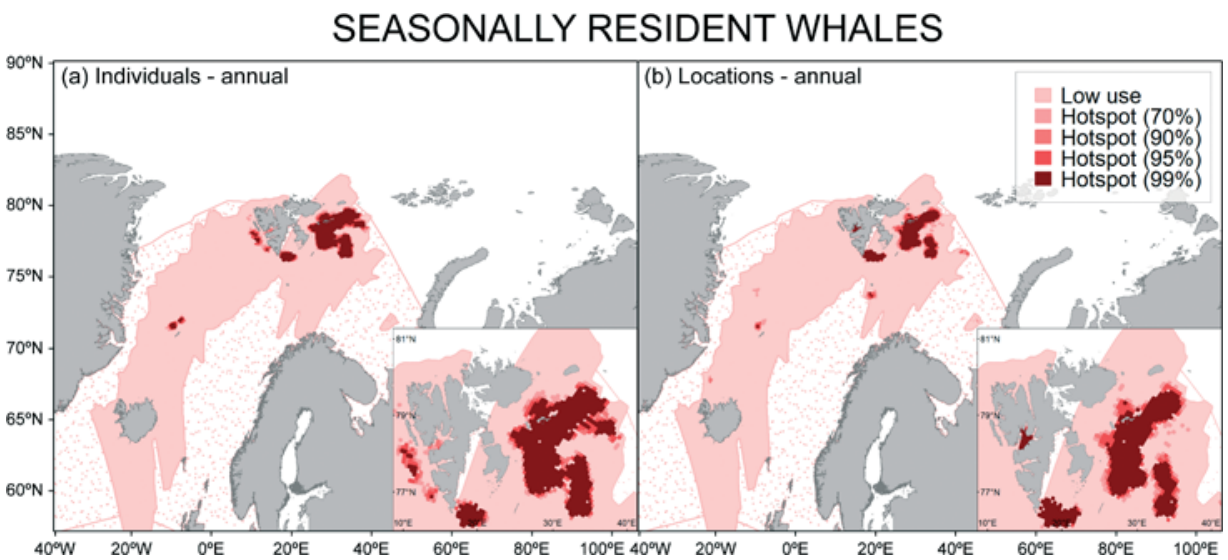

Fig. 13. Getis-Ord $G_{i}^{*}$ (a) individual hotspots and (b) location hotspots for blue, fin and humpback whales (total $\mathrm{n}=26$ seasonally resident whales) tagged around Svalbard. These species were only present in the study area during the summer/autumn. Inset maps show hotspots around the Svalbard Archipelago. Details as in Fig. 3 legend 


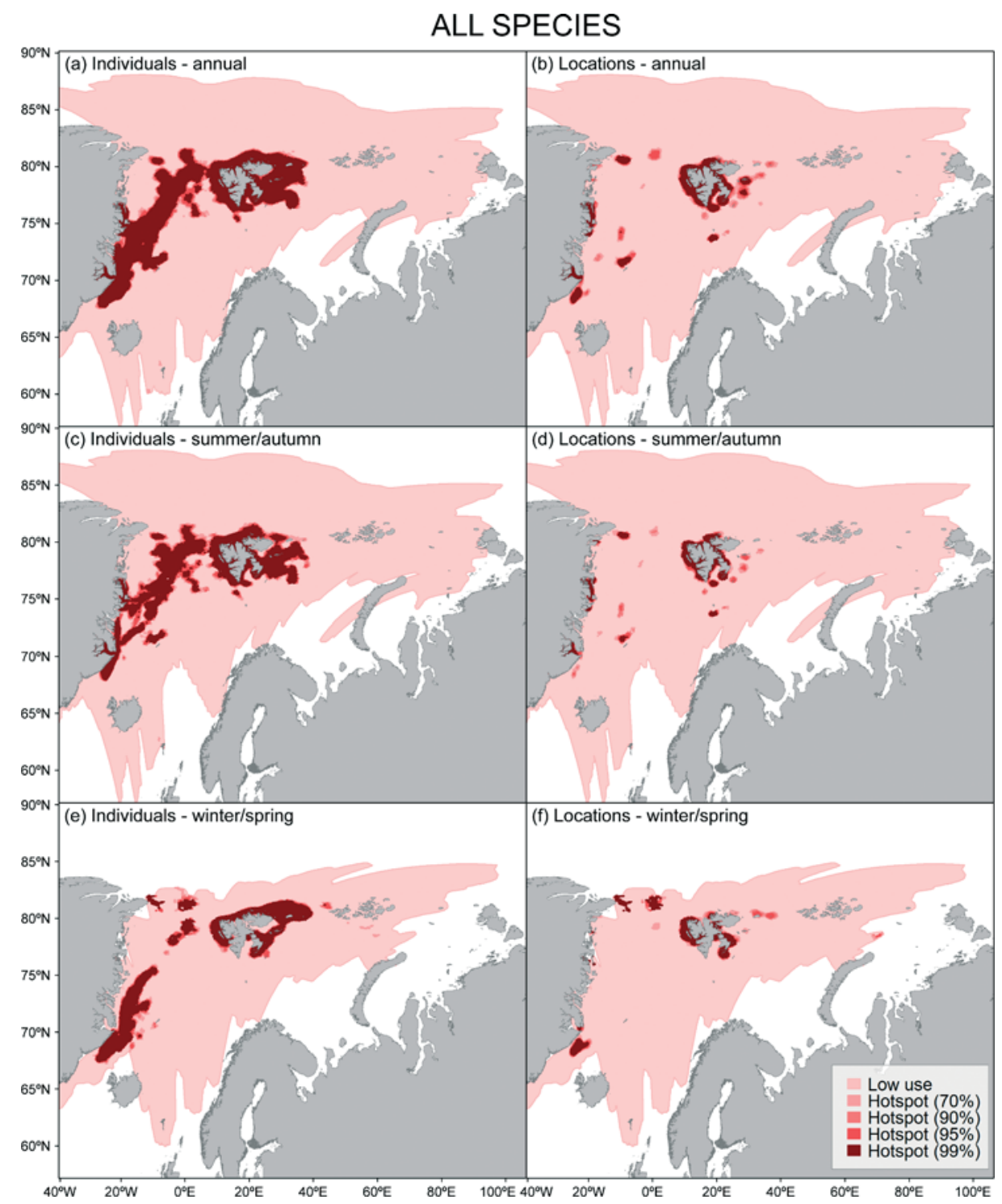

Fig. 14. Getis-Ord $G_{i}^{*}(\mathrm{a}, \mathrm{c}, \mathrm{e})$ individual hotspots and $(\mathrm{b}, \mathrm{d}, \mathrm{f})$ location hotspots for the 13 species tagged around Svalbard and Northeast Greenland over $(\mathrm{a}, \mathrm{b})$ the entire year, $(\mathrm{c}, \mathrm{d})$ during the summer/autumn and $(\mathrm{e}, \mathrm{f})$ during the winter/spring. Details as in Fig. 3 legend

\subsection{All species hotspots and species richness}

Hotspots (both individual and location) for all 13 marine mammal species were found around the Svalbard Archipelago, in coastal areas of Northeast Greenland and in the MIZ of the Greenland and northern Barents Seas (Fig. 14). These areas coincided with areas that had the greatest species richness (Figs. 15, 16). Up to $90 \%$ of the highest values of species richness occurred within high individual hotspot levels (95\% and 99\%; Table S3 in the Supplement). Overlap between high values of species richness and high hotspot levels was generally less for location hotspots compared to individual hotspots and for the winter/spring period compared to summer/autumn and annual data (Table S3 in the Supplement). Null model hotspots for all species were found mainly around western and south-eastern Svalbard and in the Greenland Sea, near the tagging areas for the different species (Fig. 2, Fig. S7e, fin the Supplement). Highly significant null model hotspot levels (95 and 99\%) overlapped all species hotspots (95 and $99 \%$ ) by $30 \%$ and $34 \%$ for individual and location hotspots, respectively (Table 3). The highest values for the species richness null model were also located west of Svalbard (Fig. S8 in the Supplement). 


\section{DISCUSSION}

The MIZ of the Greenland Sea and the northern Barents Seas and coastal areas in Northeast Greenland and around the Svalbard Archipelago were found to be hotspots for a wide range of marine mammal species in the Northeast Atlantic Arctic, as well as being areas of high species richness. The individual versus location hotspots results identified a few important differences. Individual hotspots identified areas important to the majority of tagged individuals. Examples of individual hotspot areas include common resting, moulting, breeding and foraging areas. Prins Karls Forland and the adjacent continental shelf are the main breeding, moulting, resting and foraging locations for harbour seals Phoca vitulina in Svalbard (Lydersen \& Kovacs 2010). Similarly, drift ice areas within the MIZ are used for breeding, moulting and resting by harp seals Pagophilus groenlandicus and hooded seals Cystophora cristata (Folkow et al. 2004, Vacquié-Garcia et al. 2017a). Walruses Odobenus rosmarus predominantly forage near terrestrial haul-out sites (Lowther et al. 2015), and ringed seals Pusa hispida are found throughout the year in close association with tidewater glacier fronts (Hamilton et al. 2016). In contrast, location hotspots identified areas that are used heavily, in some cases by only a few of the tagged individuals. Location hotspots were similar to individual hotspots for some species, including ringed seals, harbour seals and harp seals. However, differences in individual versus location hotspots were also found, revealing a discrepancy for some species and regions between areas frequented by many animals (i.e. individual hotspots) and areas that are highly used (not necessarily by the majority of tagged individuals; i.e. location hotspots). For these species, areas where tagged animals congregate (e.g. pupping, nursing and breeding locations) may not be the same locations in which individuals spend the majority of their time. In general, individual and location hotspot results differed for species where individuals or small groups forage in different locations across a wide geographic area or for species that perform important life-history behaviours in different locations across their range. For example, location hotspots identified areas that were previously identified as being foraging areas for hooded seals and bowhead whales Balaena mysticetus (Vacquié-Garcia et al. 2017a, Kovacs et al. 2020a). Previous analyses of the polar bear Ursus maritimus data show that many location hotspots in Northeast Greenland are denning sites (Laidre et al. 2015b). Location hotspots
SPECIES RICHNESS

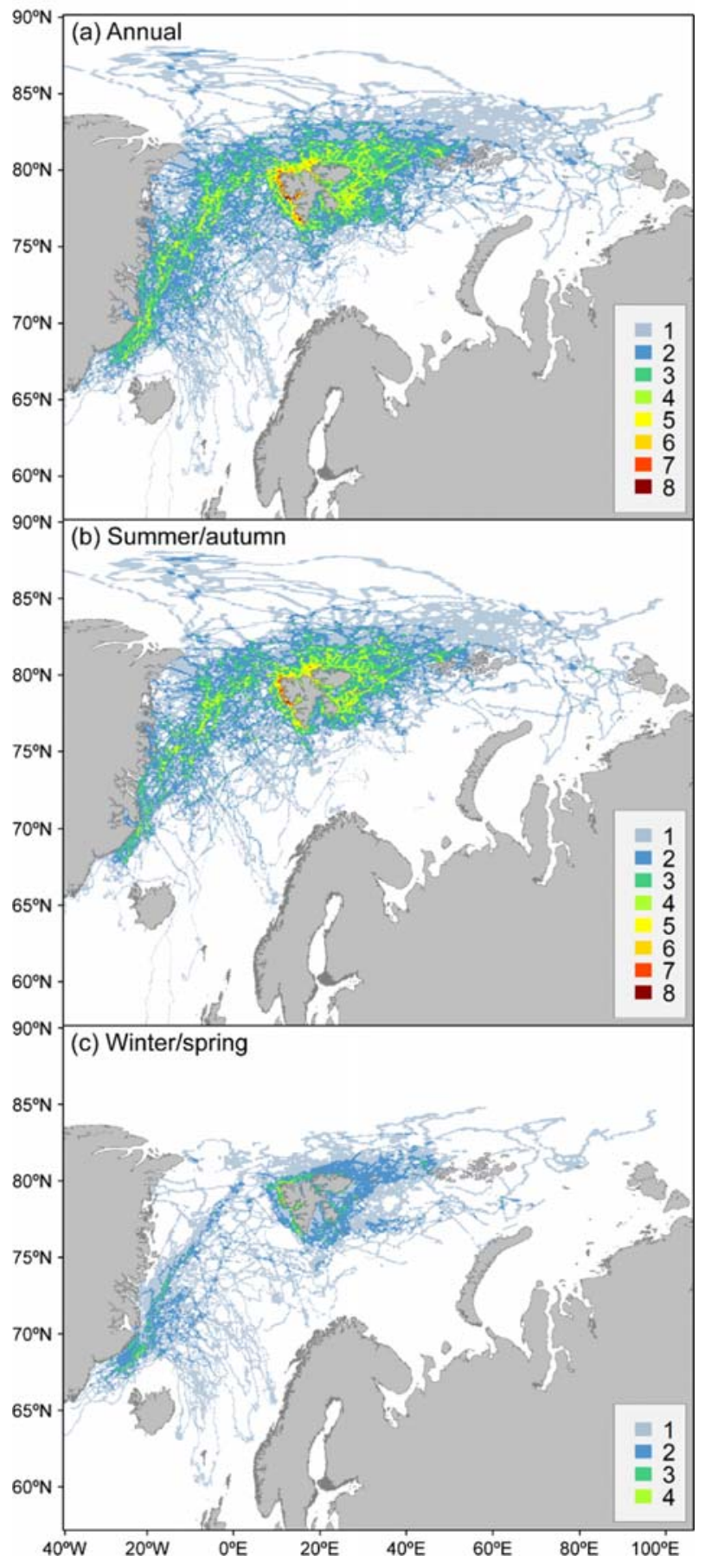

Fig. 15. Species richness (number of species in each grid cell) for the 13 species of marine mammals tagged around Svalbard and Northeast Greenland over (a) the entire year, (b) during the summer/autumn and (c) during the winter/ spring

were also found further north in the Svalbard Archipelago than individual hotspots for white whales and bearded seals, and further west for walruses, indicating that these areas were used heavily by only a few 


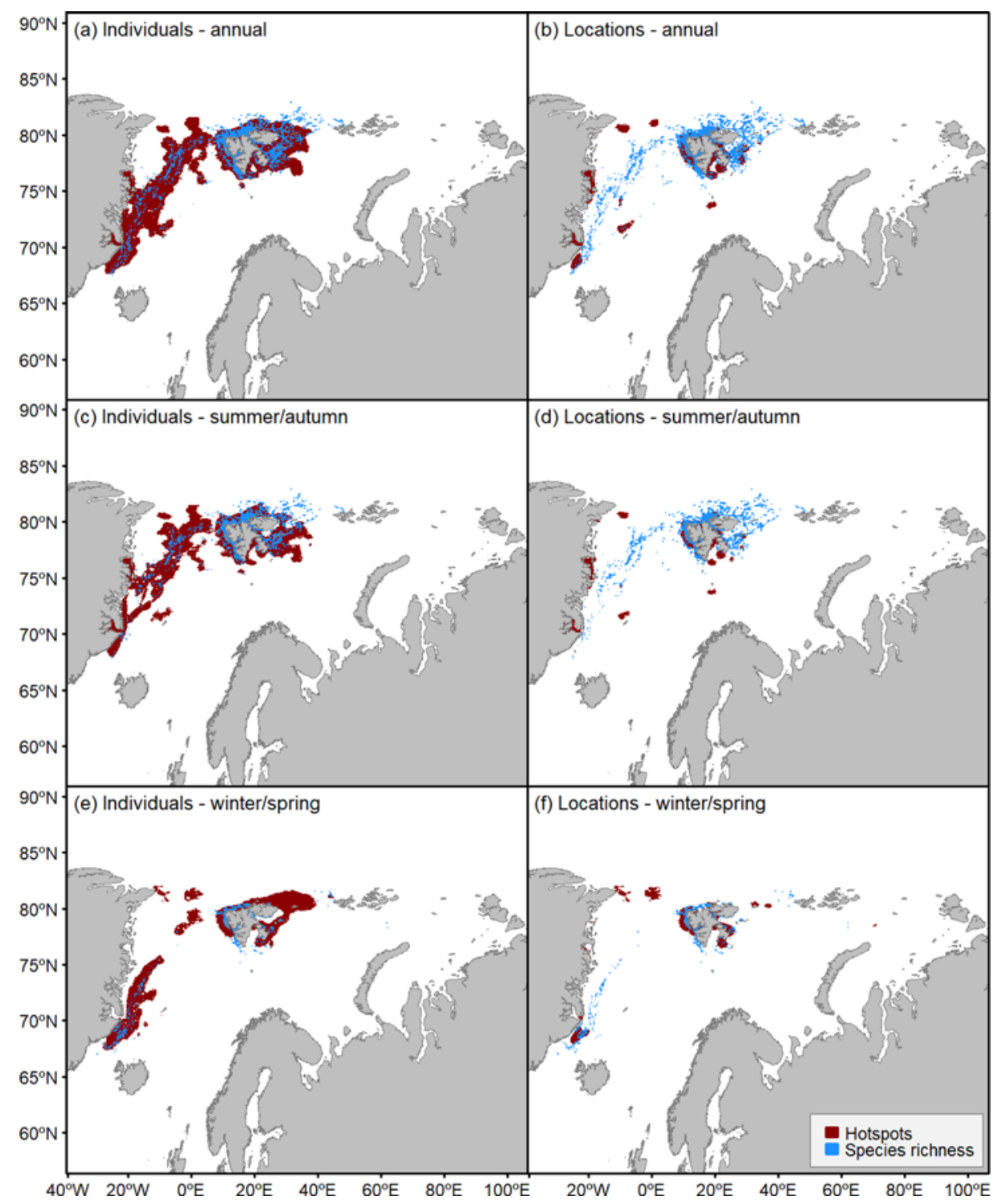

Fig. 16. Areas where overlap occurs between high values of Getis-Ord $G_{i}^{*}$ hotspots (95\% and $99 \%$ ) and areas of high species richness (4-8 species for annual and summer/autumn analyses and 2-4 species for winter/spring analyses) for (a,c,e) individual hotspots and $(b, d, f)$ location hotspots over $(a, b)$ the entire year, $(c, d)$ during the summer/autumn and $(e, f)$ during the winter/spring

of the tagged animals. Location hotspots also covered a smaller geographic area than individual hotspots for many species, meaning that areas heavily used (i.e. location hotspots) in total covered a smaller geographic area than regions visited by the majority of tagged animals (i.e. individual hotspots).

Both individual and location hotspot results are highly relevant for the development of conservation and management plans. In addition to areas important for the majority of the population (i.e. individual hotspots), conservation and management plans also need to target areas important for small segments of the population (i.e. location hotspots), particularly for rare species. Identifying the environmental features underlying important foraging or denning areas will allow plans to be expanded to additional foraging and denning areas that were likely used by untagged members of the population. Such measures will be important for species that forage over large areas either as single animals or in small groups. Denning areas of polar bears may only be used by small segments of the population, but it is important to manage disturbance risks in order to maximize survival of female bears with cubs of the year. 
Species richness values overlapped significantly with high individual hotspot levels. This overlap was generally higher around the Svalbard Archipelago than in coastal areas of Northeast Greenland. A few coastal hotspots in Northeast Greenland resulted from heavy use by a few marine mammal species. Expanded biotelemetry data collection in Northeast Greenland, especially on species where biotelemetry data are currently lacking (e.g. bearded seals), would likely increase the overlap between high species richness and hotspot levels in this region. Overlap between high values of species richness and hotspot levels was also higher for individual hotspots than for location hotspots. Regions important for the majority of a tagged population are more likely to also be important regions for additional species, in contrast to areas heavily used by smaller segments of a population.

Similarities and differences among identified hotspot areas for individual species highlight the ecological niches they each occupy. Bearded seals and walruses are both benthic foragers that feed in shallow, coastal regions (Lowther et al. 2015, Hamilton et al. 2018, 2019b), and thus they would be expected to have similar hotspots in regions where both species are found. Similarities would also be expected among species with tight coastal distributions (e.g. ringed seals and white whales Delphinapterus leucas in Svalbard; Hamilton et al. 2016, Vacquié-Garcia et al. 2018); species that are heavily dependent on sea ice (e.g. ringed seals and polar bears in the MIZ; Lone et al. 2018, 2019); and species that dive to intermediate depths in open ocean areas (e.g. harp seals and hooded seals; Folkow et al. 2004, Vacquié-Garcia et al. 2017a). However, it is important to note that species can have quite different habitat and movement patterns in different areas of their range, which could impact the breadth and location of hotspots.

Fjords and coastal areas around the Svalbard Archipelago were identified as hotspots for the majority of the marine mammals included in these analyses, and as areas of high species richness in the Northeast Atlantic Arctic, confirming work done on individual species and small species groups (e.g. Blanchet et al. 2014, Hamilton et al. 2017, 2018, Vacquié-Garcia et al. 2018). Fjords and coastal areas of Northeast Greenland were also identified as marine mammal hotspots that were used heavily by a variety of marine mammal species (e.g. Dietz et al. 1994, Boertmann \& Mosbech 2012, present study). Rapid changes are occurring in these important coastal hotspot areas. Large decreases in land-fast ice extent and duration have occurred in coastal regions of Svalbard over recent decades (Meredith et al. 2019, Pavlova et al. 2019). Additionally, the number of tidewater glacier fronts, which are important hotspots for many Arctic marine mammals, have also decreased in Svalbard (Błaszczyk et al. 2009). Retreat of tidewater glaciers onto land will likely reduce the amount of upwelling-derived nutrients, and advection towards inner fjords of production arising elsewhere, leading to decreases in productivity and accessibility of concentrated food supplies to higher trophic levels in these regions (Meredith et al. 2019). Numerous changes have already occurred in the distribution, behaviour, predator-prey relationships and breeding ecology of Arctic marine mammal species in relation to these changes in their habitat (e.g. Hamilton et al. 2016, 2017, 2019a, Vacquié-Garcia et al. 2018, Kovacs et al. 2020b). How hotspot locations may shift in the coming decades and how species will ultimately fare as the climate continues to warm are currently unknown. However, the future breeding success of bearded seals and ringed seals in relation to earlier melting of the sea ice and reduced opportunities for the latter species to build snow lairs are serious concerns for the continued existence of these Arctic seals.

The MIZ was identified as a marine mammal hotspot and an area of high species richness in the Greenland Sea and northern Barents Sea, confirming results from previous studies (e.g. Boertmann \& Mosbech 2012, Laidre et al. 2015b, Vacquié-Garcia et al. 2017b, Lone et al. 2018). The MIZ has long been recognized as a unique and important habitat for many marine mammals (as well as birds and fishes) (e.g. Stirling 1997). The spatial area covered by the MIZ is highly dynamic both intra- and inter-annually (Vinje 2009), which has a large influence on where marine mammal hotspots occur in both space and time. Hotspots for marine mammals found in the MIZ (e.g. polar bears, harp seals and hooded seals) were generally found further north in the summer/autumn than in the winter/spring, reflecting intra-annual variations in sea-ice extent. Polynyas and openings in the sea ice are also extremely important for marine mammals (Stirling 1997). Polynyas situated in the mouths of fjords and adjacent to the coast in Northeast Greenland (e.g. Northeast Water Polynya, polynya outside Scoresby Sound) and adjacent to islands in the northern Barents Sea are important over-wintering areas for many species (Born \& Knutsen 1992, Boertmann \& Mosbech 2012, Lowther et al. 2015, Kovacs et al. 2020a). These regions were identified as hotspots for bowhead whales Balaena mys- 
ticetus, walruses and narwhals Monodon monoceros in the present study.

Sea ice serves multiple functions for different Arctic marine mammal species. It is a pupping, nursing and resting habitat for Arctic seals; a hunting platform and transport corridor for polar bears; a foraging habitat for the majority of Arctic marine mammal species; and it provides protection for ice-adapted Arctic marine mammals from aquatic predators and storm events (see Kovacs et al. 2011 for details). There is thus a large conservation concern for marine mammals given the ongoing declines in sea-ice extent and volume. The extent to which Arctic marine mammals can simply shift their ranges north is currently unknown, as this would involve shifting their distributions from over the productive Arctic continental shelf seas to over the less productive, deep Arctic Ocean Basin for many species. There is considerable uncertainty regarding how the levels of primary and secondary productivity and the presence of fish and invertebrate stocks will change in the Arctic Ocean Basin as sea-ice declines continue (see e.g. Haug et al. 2017, Meredith et al. 2019). However, the northward shift of the MIZ and general decrease in sea-ice extent are already having negative consequences for many marine mammal species, including range shifts, increased foraging costs, changes in habitat use patterns and changes in terrestrial denning locations of polar bears (Derocher et al. 2011, Hamilton et al. 2015, Laidre et al. 2015b, Lone et al. 2018). Ongoing distributional shifts will undoubtedly impact the location of marine mammal hotspots in the coming decades.

Not all marine mammals in the Greenland and the Barents Sea had hotspots solely in the MIZ or coastal regions of Northeast Greenland and Svalbard. Open ocean hotspots were important for some species, especially for harp seals, hooded seals, harbour seals and seasonally resident whales. Harp seals and hooded seals make extensive use of open ocean areas for foraging in the summer and autumn (Folkow et al. 2004, Vacquié-Garcia et al. 2017a), while the shelf edge is important for harbour seals and migratory whales around Svalbard (Blanchet et al. 2014, Storrie et al. 2018). Some species seem to be showing signs of adjusting to making greater use of waters off the immediate coastline in fjords as sea-ice extent declines, including white whales and harbour seals (Vacquié-Garcia et al. 2018, Hamilton et al. 2019a, Norwegian Polar Institute's Marine Mammal Sightings Database, contact K.M.K. for more information). Seasonally resident whales have also expanded their distributional areas in northern regions following decreases in sea-ice extent (Storrie et al. 2018, Hansen et al. 2019); these 'boreal' species are likely to be climate 'winners' in the coming decades with resultant increases in their numbers and the number of areas that are hotspots for this species group in Arctic areas. However, not all species are adapting to using open ocean areas. Ringed seals continue to use their 'traditional' habitats, and polar bears are dependent on sea ice when in offshore areas as well as when they are moving between areas (transit corridors), particularly when accompanied by young cubs (Hamilton et al. 2015, 2019a, Lone et al. 2018, 2019).

Human activities are increasing in Arctic regions as declines in sea ice make these regions more accessible. These activities pose risks to marine mammals if activities overlap with identified hotspot regions. Oil and gas exploration and production are shifting northward in the study region, and levels of ship traffic are increasing (Reeves et al. 2014). Noise-induced behavioural disturbance and auditory masking from oil and gas exploration and production and boat traffic can potentially occur over large distances (Reeves et al. 2014, Halliday et al. 2017, Bröker 2019). Ships disrupting sea-ice habitat could have serious impacts on breeding and moulting groups of harp seals and hooded seals in the Greenland Sea, as has been demonstrated in the White Sea (Chernook \& Boltnev 2008). Tourism is also increasing in the Svalbard Archipelago (www.mosj.no) and in Greenland (www.stat.gl). Tourist activities have the potential to have negative impacts on marine mammals (Rode et al. 2018), although appropriate regulations managing tourism activities can help minimize impacts on marine mammals (Øren et al. 2018).

\subsection{Biases and research gaps}

The hotspot analyses herein identified areas that are important for individual species and species groups within this Arctic region. The strongest bias to the hotspot results is undoubtedly tagging location(s). Areas with less tagging effort are underrepresented in the hotspot analysis. Ideally, tags should be deployed evenly over the total distribution area of each species within the study area (Queiroz et al. 2016). The number of individuals tagged in different locations should also be weighted by the representative population sizes of a species in each area. However, the costs of this research limit the number of tags and locations where deployments take place, and population size information is lacking for most 
species. The present study was thus restricted to a simple equal-weighting option. To address this bias, null model hotspots were created for each species to illustrate where hotspots were expected based on the capture locations. The amount of overlap between null model hotspots and marine mammal hotspots varied a lot. In general, overlap was greatest for species that have restricted, local movements around their capture locations (e.g. bearded seals, harbour seals) compared to species that ranged widely throughout the study region (e.g. hooded seals, seasonally resident whales). Interpretation of the hotspot results in light of the null models is also complicated by fieldwork being carried out in areas where each species is known to occur. Harbour seals were tagged at the only known breeding area and main moulting area for this species in Svalbard (Lydersen \& Kovacs 2010). Similarly, walruses were tagged at sites known to be used heavily by this species (Kovacs et al. 2014). The overlap of hotspots with null model hotspots is unavoidable in the above examples as these are the main distributional areas for these species.

Discrepancies between marine mammal hotspots and IUCN ranges serve as a useful gap analysis that highlights areas and species where more research is needed. Polar bears with an inshore movement strategy were under-represented in the biotelemetry data from Northeast Greenland because most of the polar bears tagged in East Greenland were caught offshore in the north (Laidre et al. 2015b). Therefore, few coastal hotspots in the northeast and no hotspots in Southeast Greenland were identified, even though polar bears reside in these regions year-round (Boertmann \& Mosbech 2012, Laidre et al. 2018). A small number of tagging locations throughout a species' distributional area is exacerbated by localized movement patterns of some species (e.g. bearded seals, ringed seals), leading to large discrepancies between hotspot areal coverage and species' ranges. In the Northeast Atlantic, more marine mammal biotelemetry data are needed in eastern Svalbard, around Nordaustlandet, in East Greenland and particularly around Franz Josef Land. Species for which more research effort is needed include bearded seals, ringed seals, walruses, harp seals and narwhals due to low areal coverage or paucity of current data from one of the sexes or from various age classes. Tagging effort needs to be continued through the coming decades to document shifting hotspot locations as climate change continues.

Sex and age class were not included in the hotspot analyses as the proportion of individuals tagged of different sex and age classes was variable among the tagged species. For example, all of the data for harp seals in this study were from pups, and only male walruses and mostly female polar bears were tagged. The different age classes of some species have similar space-use patterns (e.g. Folkow et al. 2004, 2010, Blanchet et al. 2016, Hamilton et al. 2019b), but differences in space-use patterns between the different sexes, age classes and life history stages have been documented for many species in this region (e.g. Freitas et al. 2012, Kovacs et al. 2014, Hamilton et al. 2015, 2016). Biases may also result if some age classes or one of the sexes have a longer tracking duration than the rest of the population. This is because individuals with longer tracking durations will have a larger impact on the hotspots results than those with shorter tracking durations. The biotelemetry tags deployed on male polar bears (i.e. ear tags) have shorter battery lives than the tags deployed on female polar bears (i.e. collars; Wiig et al. 2017), biasing hotspot results towards areas used by female polar bears, especially during time periods and in regions when only data from female bears exist. Efforts should be made to deploy instruments on both sexes and various age groups of all species in order to identify similarities and differences in movement strategies, behaviour and hotspot location.

\subsection{Conclusions}

This study consolidated biotelemetry data from marine mammals in the Greenland and northern Barents Seas in order to identify where marine mammal hotspots and areas of high species richness occur. The results clearly show that the MIZ of the Greenland Sea and northern Barents Sea and coastal regions and fjords of Svalbard and Northeast Greenland are marine mammal hotspots and areas of high species richness. Protection in the form of management and conservation plans is needed in these habitats to help guard against a myriad of threats from climate change and expanding human activities. Due to the high inter- and intra-annual variability in the location and extent of the MIZ and the resultant identified shifts in seasonal locations of marine mammal hotspots, conservation and management plans targeting this important marine mammal habitat will need to be flexible in both space and time in order to protect the many species that use this dynamic zone (see e.g. Pressey et al. 2007, Game et al. 2009, D'Aloia et al. 2019). Many seabird and fish species are also found in the MIZ due to its high summer pulse of biological 
productivity as well as in coastal regions of Svalbard and East Greenland (e.g. Gulliksen \& Lønne 1989, Hunt et al. 1996, Hop \& Gjøsæter 2013); conservation measures targeting these regions will positively benefit many groups of Arctic biota.

Acknowledgements. This work was supported by the Norwegian Research Council (including the bearded seal ecology, ICEwhales and Glære programs), the Norwegian Polar Institute's Ice, Climate and Ecosystem Centre, Fram Centre's Fjord and Coast Flagship, The Norwegian-Russian Environmental Commission, the Regional Norwegian Research Council (RFFNORD 282469), the Bureau of Mineral and Petroleum (Nuuk, Greenland), the Danish Ministry of the Environment and the Greenland Institute of Natural Resources. We thank all field team members for assistance in capturing and tagging marine mammals as well as the crews of MV 'Nordsyssel' (Institute of Marine Research), RV 'Lance' (Norwegian Polar Institute - NPI), RV 'Kronprins Haakon' (NPI), RV 'Helmer Hanssen' (UiT - the Arctic University of Norway) and KV 'Svalbard' (Norwegian Coast Guard). We thank Benjamin Merkel and Marie-Anne Blanchet for preparation of the Svalbard polar bear data and Mikhail Itkin for preparing the sea-ice concentration shapefiles.

\section{LITERATURE CITED}

Ahonen H, Stafford KM, de Steur L, Lydersen C, Wiig Ø, Kovacs KM (2017) The underwater soundscape in western Fram Strait: breeding ground of Spitsbergen's endangered bowhead whales. Mar Pollut Bull 123: 97-112

Barry RP, McIntyre J (2011) Estimating animal densities and home range in regions with irregular boundaries and holes: a lattice-based alternative to the kernel density estimator. Ecol Modell 222:1666-1672

Bivand RS, Wong DWS (2018) Comparing implementations of global and local indicators of spatial association. Test 27:716-748

Blanchet MA, Lydersen C, Ims RA, Lowther AD, Kovacs KM (2014) Harbour seal Phoca vitulina movement patterns in the high-Arctic archipelago of Svalbard, Norway. Aquat Biol 21:167-181

Blanchet MA, Lydersen C, Ims RA, Kovacs KM (2016) Making it through the first year: Ontogeny of movement and diving behaviour in harbor seals from Svalbard, Norway. Mar Mamm Sci 32:1340-1369

Błaszczyk M, Jania JA, Hagen JO (2009) Tidewater glaciers of Svalbard: recent changes and estimates of calving fluxes. Pol Polar Res 30:85-142

Boertmann D, Mosbech A (eds) (2012) The Western Greenland Sea, a strategic environmental impact assessment of hydrocarbon activities. Scientific Report from Danish Centre for Environment and Energy no. 22. Aarhus University, Roskilde, Denmark

Born EW, Knutsen LØ (1992) Satellite-linked radio tracking of Atlantic walruses (Odobenus rosmarus rosmarus) in northeast Greenland 1989-1991. Z Saugetierkd 57: 275-287

Bröker KC (2019) An overview of potential impacts of hydrocarbon exploration and production on marine mammals and associated monitoring and mitigation measures. Aquat Mamm 45:576-611

* Calenge C (2006) The package 'adehabitat' for the R software: a tool for the analysis of space and habitat use by animals. Ecol Modell 197:516-519.

Chernook VI, Boltnev AI (2008) Regular instrumental aerial surveys detect a sharp drop in the birth rates of the harp seal in the White Sea. In: Boltunov A (ed) Collection of Scientific Papers from the Marine Mammals of the Holarctic V Conference. Odessa, Ukraine, 14-18 October, p 100-104

* Citta JJ, Lowry LF, Quakenbush LT, Kelly BP, and others (2018) A multi-species synthesis of satellite telemetry data in the Pacific Arctic (1987-2015): Overlap of marine mammal distributions and core use areas. Deep Sea Res II 152:132-153

* Collecte Localisation Satellites (CLS) (2016) Argos user's manual. www.argos-system.org/manual (accessed 10 Jun 2019)

* D'Aloia CC, Naujokaitis-Lewis I, Blackford C, Chu C and others (2019) Coupled networks of permanent protected areas and dynamic conservation areas for biodiversity conservation under climate change. Front Ecol Evol 7:27

Derocher AE, Andersen M, Wiig Ø, Aars J, Hansen E, Biuw M (2011) Sea ice and polar bear den ecology at Hopen Island, Svalbard. Mar Ecol Prog Ser 441:273-279

Dietz R, Heide-Jørgensen MP, Born EW, Glahder CM (1994) Occurrence of narwhals (Monodon monoceros) and white whales (Delphiapterus leucas) in East Greenland. Medd Gronl Biosci 39:69-86

*Douglas DC, Weinzierl R, Davidson SC, Kays R, Wikelski M, Bohrer G (2012) Moderating Argos location errors in animal tracking data. Methods Ecol Evol 3:999-1007

Folkow LP, Nordøy ES, Blix AS (2004) Distribution and diving behaviour of harp seals (Pagophilus groenlandicus) from the Greenland Sea stock. Polar Biol 27:281-298

Folkow LP, Nordøy ES, Blix AS (2010) Remarkable development of diving performance and migrations of hooded seal (Cystophora cristata) during their first year of life. Polar Biol 33:433-441

* Fossheim M, Primicerio R, Johannesen E, Ingvaldsen RB, Aschan MM, Dolgov AV (2015) Recent warming leads to a rapid borealization of fish communities in the Arctic. Nat Clim Chang 5:673-677

Freitas C, Lydersen C, Fedak MA, Kovacs KM (2008) A simple new algorithm to filter marine mammal Argos locations. Mar Mamm Sci 24:315-325

* Freitas C, Kovacs KM, Andersen M, Aars J and others (2012) Importance of fast ice and glacier fronts for female polar bears and their cubs during spring in Svalbard, Norway. Mar Ecol Prog Ser 447:289-304

* Game ET, Grantham HS, Hobday AJ, Pressey RL and others (2009) Pelagic protected areas: the missing dimension in ocean conservation. Trends Ecol Evol 24:360-369

Getis A, Ord JK (1992) The analysis of spatial association by use of distance statistics. Geogr Anal 24:189-206

Gulliksen B, Lønne OJ (1989) Distribution, abundance, and ecological importance of marine sympagic fauna in the Arctic. Rapp P-V Reùn Cons Int Explor Mer 188:133-138

*Halliday WD, Insley SJ, Hilliard RC, de Jong T, Pine MK (2017) Potential impacts of shipping noise on marine mammals in the western Canadian Arctic. Mar Pollut Bull 123:73-82

*Hamilton CD, Lydersen C, Ims RA, Kovacs KM (2015) Predictions replaced by facts: a keystone species' behav- 
ioural responses to declining arctic sea-ice. Biol Lett 11: 20150803

Hamilton CD, Lydersen C, Ims RA, Kovacs KM (2016) Coastal habitat use by ringed seals Pusa hispida following a regional sea-ice collapse: importance of glacial refugia in a changing Arctic. Mar Ecol Prog Ser 545: 261-277

Hamilton CD, Kovacs KM, Ims RA, Aars J, Lydersen C (2017) An Arctic predator-prey system in flux: climate change impacts on coastal space use by polar bears and ringed seals. J Anim Ecol 86:1054-1064

Hamilton CD, Kovacs KM, Lydersen C (2018) Individual variability in diving, movement and activity patterns of adult bearded seals in Svalbard, Norway. Sci Rep 8:1698

Hamilton CD, Vacquié-Garcia J, Kovacs KM, Ims RA, Kohler J, Lydersen C (2019a) Contrasting changes in space use induced by climate change in two Arctic marine mammal species. Biol Lett 15:20180834

*Hamilton CD, Lydersen C, Fedak MA, Freitas C, Hindell MA, Kovacs KM (2019b) Behavioural ontogeny of bearded seals Erignathus barbatus through the first year of life. Mar Ecol Prog Ser 627:179-194

Hansen RG, Boye TK, Larsen RS, Nielsen NH and others (2019) Abundance of whales in West and East Greenland in summer 2015. NAMMCO Sci Publ 11 doi:10.7557/ 3.4689

*Haug T, Bogstad B, Chierici M, Gjøsæter H, and others (2017) Future harvest of living resources in the Arctic Ocean north of the Nordic and Barents Seas: A review of possibilities and constraints. Fish Res 188:38-57

Heide-Jørgensen MP, Nielsen NH, Hansen RG, Schmidt HC, Blackwell SB, Jørgensen OA (2015) The predictable narwhal: satellite tracking shows behavioural similarities between isolated populations. J Zool 297:54-65

* Higdon JW, Ferguson SH (2009) Loss of Arctic sea ice causing punctuated change in sightings of killer whales (Orcinus orca) over the past century. Ecol Appl 19: 1365-1375

Hop H, Gjøsæter H (2013) Polar cod (Boreogadus saida) and capelin (Mallotus villosus) as key species in marine food webs of the Arctic and the Barents Sea. Mar Biol Res 9: 878-894

Hunt GL, Bakken V, Mehlum F (1996) Marine birds in the marginal ice zone of the Barents Sea in late winter and spring. Arctic 49:53-61

KICES (2019) ICES Barents Sea ecoregion-Ecosystem overview. In: Report of the ICES Advisory Committee, 2019. ICES Advice 2019, Section 5.1

Ingvaldsen R, Loeng H (2009) Physical oceanography. In: Sakshaug E, Johnsen G, Kovacs K (eds) Ecosystem Barents Sea. Tapir Academic Press, Trondheim, Norway, p 33-64

IPCC (2018) Summary for policymakers. In: Masson-Delmotte V, Zhai P, Pörtner H-O, Roberts D and others (eds) Global warming of $1.5^{\circ} \mathrm{C}$. An IPCC special report on the impacts of global warming of $1.5^{\circ} \mathrm{C}$ above pre-industrial levels and related global greenhouse gas emission pathways, in the context of strengthening the global response to the threat of climate change, sustainable development, and efforts to eradicate poverty. World Meteorological Organization, Geneva

IUCN (2020) The IUCN Red List of Threatened Species. Version 2020-2. (downloaded 3 Jul 2020)

Johnson DS, London JM, Lea MA, Durban JW (2008) Continuous-time correlated random walk model for animal telemetry data. Ecology 89:1208-1215

Kovacs KM, Haug T, Lydersen C (2009) Marine mammals of the Barents Sea. In: Sakshaug E, Johnsen G, Kovacs K (eds) Ecosystem Barents Sea. Tapir Academic Press, Trondheim, p 453-496

Kovacs KM, Lydersen C, Overland JE, Moore SE (2011) Impacts of changing sea-ice conditions on Arctic marine mammals. Mar Biodivers 41:181-194

Kovacs KM, Aars J, Lydersen C (2014) Walruses recovering after $60+$ years of protection in Svalbard, Norway. Polar Res 33:26034

Kovacs KM, Lydersen C, Vacquié-Garcia J, Shpak O, Glazov D, Heide-Jørgensen MP (2020a) The endangered Spitsbergen bowhead whales' secrets revealed after hundreds of years in hiding. Biol Lett 16:20200148

Kovacs KM, Krafft BA, Lydersen C (2020b) Bearded seal (Erignathus barbatus) birth mass and pup growth in periods with contrasting ice conditions in Svalbard, Norway. Mar Mamm Sci 36:276-284

* Laidre KL, Stirling I, Lowry LF, Wiig $\varnothing$, Heide-Jørgensen MP, Ferguson SH (2008) Quantifying the sensitivity of Arctic marine mammals to climate-induced habitat change. Ecol Appl 18:S97-S125

* Laidre KL, Born EW, Gurarie E, Wiig $\varnothing$, Dietz R, Stern H (2013) Females roam while males patrol: divergence in breeding season movements of pack-ice polar bears (Ursus maritimus). Proc Biol Sci 280:20122371

K Laidre KL, Stern H, Kovacs KM, Lowry L, and others (2015a) Arctic marine mammal population status, sea ice habitat loss, and conservation recommendations for the $21^{\text {st }}$ century. Conserv Biol 29:724-737

Laidre KL, Born EW, Heagerty P, Wiig Ø, and others (2015b) Shifts in female polar bear (Ursus maritimus) habitat use in East Greenland. Polar Biol 38:879-893

* Laidre KL, Northey AD, Ugarte F (2018) Traditional knowledge about polar bears (Ursus maritimus) in East Greenland: changes in the catch and climate over two decades. Front Mar Sci 5:135

*Lone K, Merkel B, Lydersen C, Kovacs KM, Aars J (2018) Sea ice resource selection models for polar bears in the Barents Sea subpopulation. Ecography 41:567-578

* Lone K, Hamilton CD, Aars J, Lydersen C, Kovacs KM (2019) Summer habitat selection by ringed seals (Pusa hispida) in the drifting sea ice of the northern Barents Sea. Polar Res 38:3483

* Lowther AD, Kovacs KM, Griffiths D, Lydersen C (2015) Identification of motivational state in adult male Atlantic walruses inferred from changes in diving and movement behaviour. Mar Mamm Sci 31:1291-1313

*LLydersen C, Kovacs KM (2010) Status and biology of harbour seals (Phoca vitulina) in Svalbard. NAMMCO Sci Publ 8:47-60

KLydersen C, Freitas C, Wiig Ø, Bachmann L, Heide-Jørgensen MP, Swift R, Kovacs KM (2012) Lost highway not forgotten: satellite tracking of a bowhead whale (Balaena mysticetus) from the critically endangered Spitsbergen Stock. Arctic 65:76-86

Meredith M, Sommerkorn M, Cassotta S, Derksen C and others (2019) Polar regions. In: Pörtner H-O, Roberts DC, Masson-Delmotte V, Zhai P and others (eds) IPCC Special Report on the Ocean and Cryosphere in a Changing Climate. In press

Ord JK, Getis A (1995) Local spatial autocorrelation statistics: distributional issues and an application. Geogr Anal $27: 286-306$ 
Øren K, Kovacs KM, Yoccoz NG, Lydersen C (2018) Assessing site-use and sources of disturbance at walrus haulouts using monitoring cameras. Polar Biol 41:1737-1750

Pavlova O, Gerland S, Hop H (2019) Changes in sea-ice extent and thickness in Kongsfjorden, Svalbard (2003-2016). In: Hop H, Wiencke C (eds) The ecosystem of Kongsfjorden, Svalbard. Advances in polar ecology, Vol 2. Springer, Cham, p 105-136

Port of Longyearbyen (2020) Statistics Port of Longyearbyen 2007, 2012-2019. https://portlongyear.no/wp-content/ uploads/2020/02/Ba\%CC\%8Attrafikk_2007_2012-2019. pdf (accessed 2 Oct 2020)

Pressey RL, Cabeza M, Watts ME, Cowling RM, Wilson KA (2007) Conservation planning in a changing world. Trends Ecol Evol 22:583-592

Queiroz N, Humphries NE, Mucientes G, Hammerschlag N, and others (2016) Ocean-wide tracking of pelagic sharks reveals extent of overlap with longline fishing hotspots. Proc Natl Acad Sci USA 113:1582-1587

R Core Team (2019) R: A language and environment for statistical computing. R Foundation for Statistical Computing, Vienna

Reeves RR, Ewins PJ, Agbayani S, Heide-Jørgesen MP, and others (2014) Distribution of endemic cetaceans in relation to hydrocarbon development and commercial shipping in a warming Arctic. Mar Policy 44:375-389

Rode KD, Wilson RR, Regehr EV, St. Martin M, Douglas DC, Olson J (2015) Increased land use by Chukchi Sea polar bears in relation to changing sea ice conditions. PLOS ONE 10:e0142213

Rode KD, Fortin-Noreus JK, Garshelis D, Dyck M, and others (2018) Survey-based assessment of the frequency and potential impacts of recreation on polar bears. Biol Conserv 227:121-132

Rudels B, Fahrbach E, Meincke J, Budéus G, Eriksson P (2002) The East Greenland Current and its contribution to the Denmark Strait overflow. ICES J Mar Sci 59: 1133-1154

Sakshaug E, Johnsen G, Kristiansen S, von Quillfeldt C, Rey F, Slagstad D, Thingstad F (2009) Phytoplankton and primary production. In: Sakshaug E, Johnsen G, Kovacs K (eds) Ecosystem Barents Sea. Tapir Academic Press, Trondheim, p 167-208

Stirling I (1997) The importance of polynyas, ice edges, and leads to marine mammals and birds. J Mar Syst 10:9-21

Storrie L, Lydersen C, Andersen M, Wynn RB, Kovacs KM (2018) Determining the species assemblage and habitat

Editorial responsibility: Kyle Elliott,

Sainte-Anne-de-Bellevue, Québec, Canada

Reviewed by 3 anonymous referees use of cetaceans in the Svalbard Archipelago, based on observations from 2002 to 2014. Polar Res 37:1463065

Tverberg V, Skogseth R, Cottier F, Sundfjord A and others (2019) The Kongsfjorden Transect: seasonal and interannual variability in hydrography. In: Hop $\mathrm{H}$, Wiencke C (eds) The ecosystem of Kongsfjorden, Svalbard. Advances in polar ecology, Vol 2. Springer, Cham, p 49-104

Vacquié-Garcia J, Lydersen C, Biuw M, Haug T, Fedak MA, Kovacs KM (2017a) Hooded seal Cystophora cristata foraging areas in the Northeast Atlantic Ocean-Investigated using three complementary methods. PLOS ONE 12:e0187889

Vacquié-Garcia J, Lydersen C, Marques TA, Aars J and others (2017b) Late summer distribution and abundance of ice-associated whales in the Norwegian High Arctic. Endang Species Res 32:59-70

*Vacquié-Garcia J, Lydersen C, Ims RA, Kovacs KM (2018) Habitats and movement patterns of white whales Delphinapterus leucas in Svalbard, Norway in a changing climate. Mov Ecol 6:21

VanWormer E, Mazet JAK, Hall A, Gill VA and others (2019) Viral emergence in marine mammals in the North Pacific may be linked to Arctic sea ice reduction. Sci Rep 9: 15569

Vinje T (2009) Sea-ice. In: Sakshaug E, Johnsen G, Kovacs K (eds) Ecosystem Barents Sea. Tapir Academic Press, Trondheim, p 65-83

WWatt CA, Orr J, Ferguson SH (2016) A shift in foraging behaviour of beluga whales Delphinapterus leucas from the threatened Cumberland Sound population may reflect a changing Arctic food web. Endang Species Res 31:259-270

*Wessel P, Smith WHF (1996) A global, self-consistent, hierarchical, high-resolution shoreline database. J Geophys Res 101:8741-8743

*Wiig Ø, Born EW, Laidre KL, Dietz R, and others (2017) Performance and retention of lightweight satellite radio tags applied to the ears of polar bears (Ursus maritimus). Anim Biotelem 5:9

* Yurkowski DJ, Hussey NE, Ferguson SH, Fisk AT (2018) A temporal shift in trophic diversity among a predator assemblage in a warming Arctic. R Soc Open Sci 5: 180259

Yurkowski DJ, Auger-Méthé M, Mallory ML, Wong SNP, and others (2019) Abundance and species diversity hotspots of tracked marine predators across the North American Arctic. Divers Distrib 25:328-345

Submitted: July 24, 2020

Accepted: November 13, 2020

Proofs received from author(s): February 1, 2021 